\title{
\#USGS
}

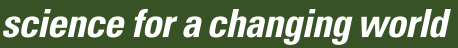

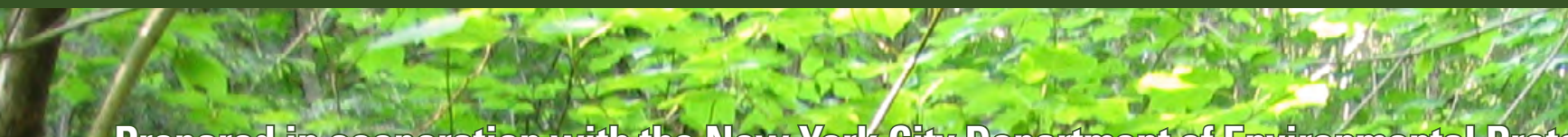

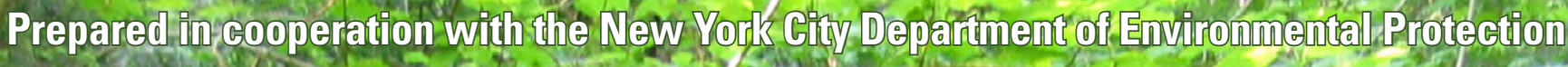

US. ceological Survereats

Water - 0uality Netwo od

Water-0uality Repont Water Yeare2006

Data Series 497
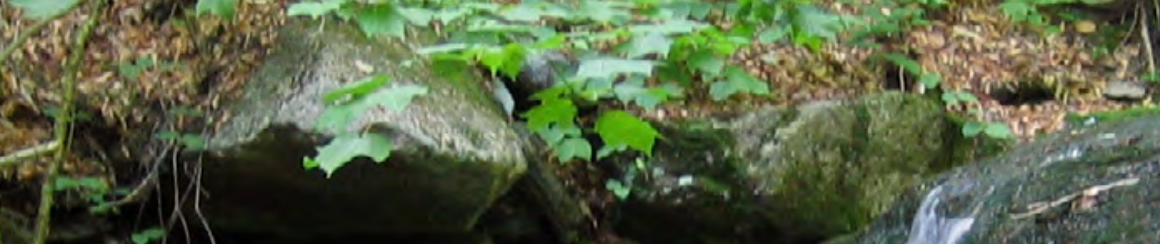

$\times 1$
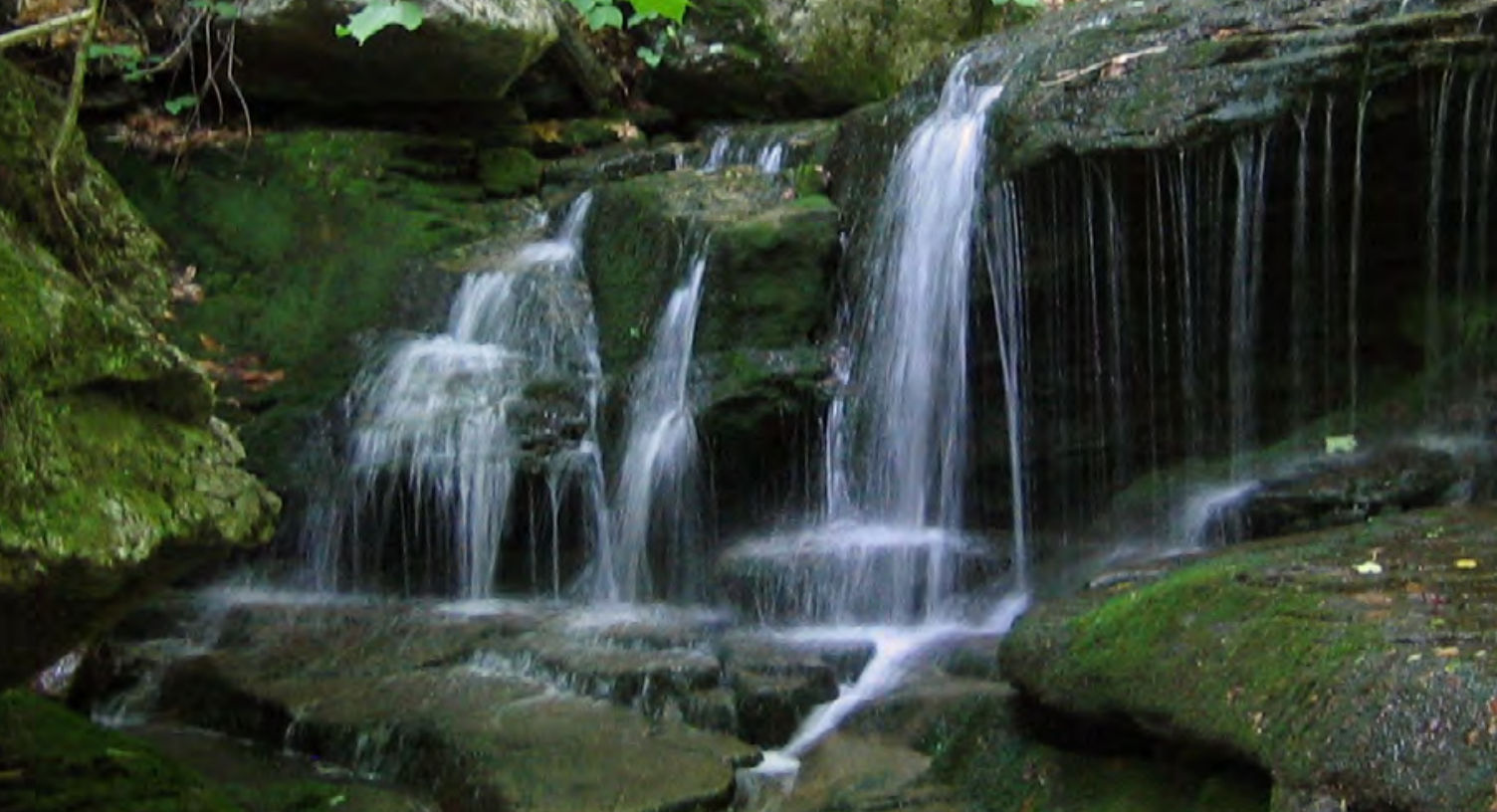

Series 497

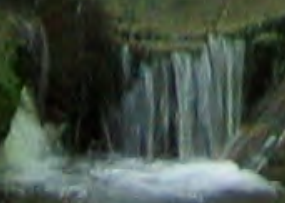

U.S. Department of the Interior

U.S. Geological Survey 
Cover. Photograph shows Biscuit Brook tributary in the Catskill Mountains of New York. 


\section{U.S. Geological Survey Catskill/Delaware Water-Quality Network: Water-Quality Report Water Year 2006}

By Michael R. McHale and Jason Siemion

Prepared in cooperation with the

New York City Department of Environmental Protection

Data Series 497 


\section{U.S. Department of the Interior \\ KEN SALAZAR, Secretary \\ U.S. Geological Survey \\ Marcia K. McNutt, Director}

U.S. Geological Survey, Reston, Virginia: 2010

For more information on the USGS—-the Federal source for science about the Earth, its natural and living resources,
natural hazards, and the environment, visit http://www.usgs.gov or call 1-888-ASK-USGS
For an overview of USGS information products, including maps, imagery, and publications,
visit http://www.usgs.gov/pubprod
To order this and other USGS information products, visit http://store.usgs.gov

Any use of trade, product, or firm names is for descriptive purposes only and does not imply endorsement by the U.S. Government.

Although this report is in the public domain, permission must be secured from the individual copyright owners to reproduce any copyrighted materials contained within this report.

Suggested citation:

McHale, M.R., and Siemion, Jason, 2010, U.S. Geological Survey Catskill/Delaware water-quality network: Water-quality report water year 2006: U.S. Geological Survey Data Series 497, 36 p., at http://pubs.usgs.gov/ds/497/. 


\section{Contents}

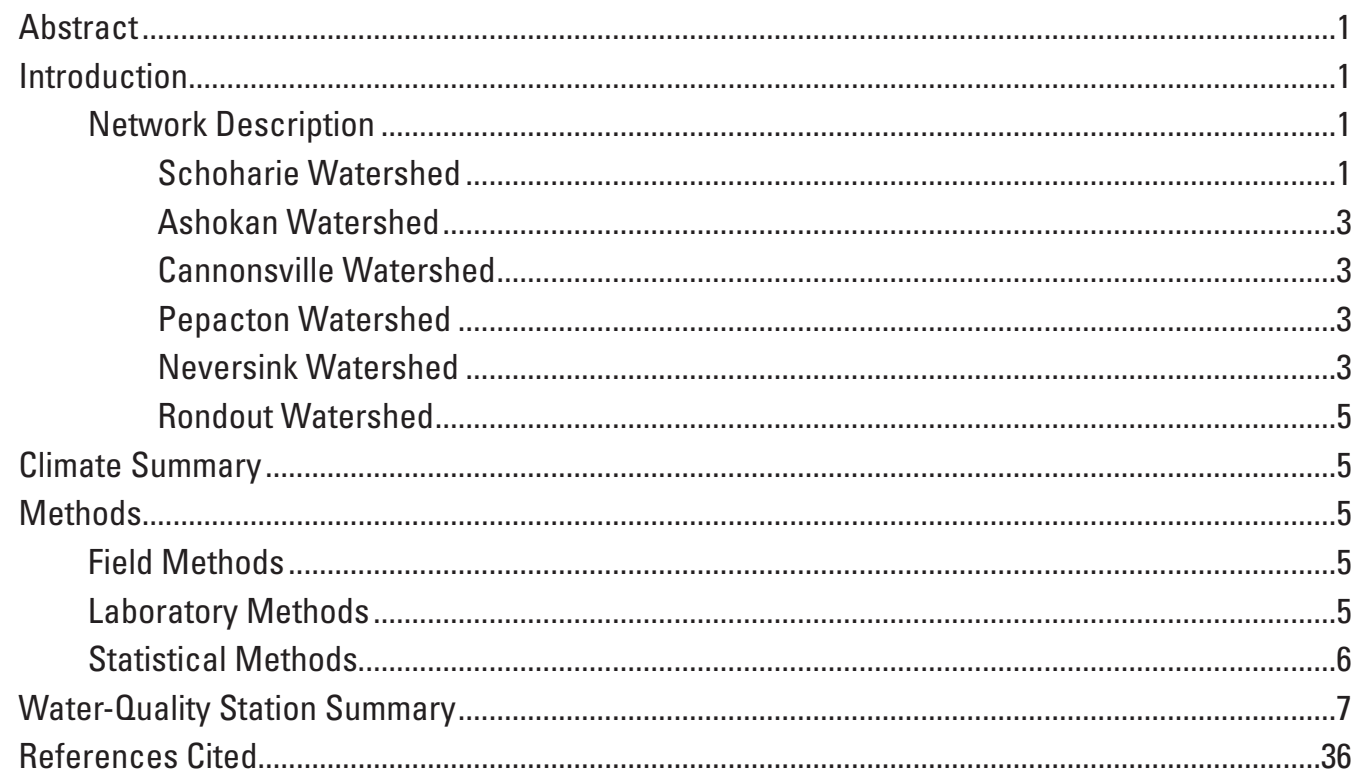

\section{Figure}

1. Map showing the New York City Catskill/Delaware Water Supply System and locations of water-quality sampling stations and streamgaging stations on selected streams in New York

\section{Table}

1. Characteristics for water-quality stations in or associated with the U.S. Geological Survey Catskill/Delaware Water Quality Network in the Catskill Mountains, New York 


\section{Conversion Factors, Datum, Abbreviations, and Units}

Inch/Pound to SI

\begin{tabular}{lcl}
\hline \multicolumn{1}{c}{ Multiply } & By & \multicolumn{1}{c}{ To obtain } \\
\hline inch (in.) & Length & \\
foot (ft) & 2.54 & centimeter $(\mathrm{cm})$ \\
mile (mi) & 0.3048 & meter $(\mathrm{m})$ \\
\hline \multicolumn{3}{c}{ Area } \\
\hline acre & 1.609 & kilometer $(\mathrm{km})$ \\
square mile $\left(\mathrm{mi}^{2}\right)$ & 0.4047 & hectare (ha) \\
square mile $\left(\mathrm{mi}^{2}\right)$ & 259.0 & hectare (ha) \\
\hline & 2.590 & square kilometer $\left(\mathrm{km}^{2}\right)$ \\
\hline foot per second $(\mathrm{ft} / \mathrm{s})$ & Flow rate & \\
cubic foot per second $\left(\mathrm{ft}^{3} / \mathrm{s}\right)$ & 0.3048 & meter per second $(\mathrm{m} / \mathrm{s})$ \\
& 0.02832 & cubic meter per second $\left(\mathrm{m}^{3} / \mathrm{s}\right)$ \\
\hline
\end{tabular}

Temperature in degrees Celsius $\left({ }^{\circ} \mathrm{C}\right)$ may be converted to degrees Fahrenheit $\left({ }^{\circ} \mathrm{F}\right)$ as follows:

$$
{ }^{\circ} \mathrm{F}=\left(1.8 \times{ }^{\circ} \mathrm{C}\right)+32
$$

Elevation data is referenced to the North American Vertical Datum of 1988.

Horizontal coordinate information is referenced to the North American Datum of 1983 (NAD 83).

Specific conductance is given in microsiemens per centimeter at 25 degrees Celsius $\left(\mu \mathrm{S} / \mathrm{cm}\right.$ at $\left.25^{\circ} \mathrm{C}\right)$.

Concentrations of chemical constituents in water are given either in milligrams per liter (mg/L) or micromoles per liter ( $\mu \mathrm{mol} / \mathrm{L})$. 
ABBREVIATIONS

\begin{tabular}{|c|c|}
\hline Abbreviation & Parameter or constituent \\
\hline $\mathrm{pH}$ & $\mathrm{pH}$ is the negative logarithm of the hydrogen ion concentration \\
\hline ANC & Acid neutralizing capacity \\
\hline Spec Cond & Specific conductance \\
\hline Temp C & Water temperature in degrees Celsius \\
\hline $\mathrm{Ca}^{2+}$ & Calcium \\
\hline $\mathrm{Mg}^{2+}$ & Magnesium \\
\hline $\mathrm{Na}^{+}$ & Sodium \\
\hline $\mathrm{K}^{+}$ & Potassium \\
\hline $\mathrm{NH}_{4}^{+}$ & Ammonium \\
\hline $\mathrm{Cl}^{-}$ & Chloride \\
\hline $\mathrm{NO}_{3}^{-}$ & Nitrate \\
\hline $\mathrm{SO}_{4}{ }^{2-}$ & Sulfate \\
\hline $\mathrm{SiO}_{2}$ & Silicon dioxide \\
\hline $\mathrm{DOC}$ & Dissolved organic carbon \\
\hline Al & Aluminum \\
\hline Almono & Total monomeric aluminum \\
\hline Alorg & Organic monomeric aluminum \\
\hline Altd & Total aluminum \\
\hline TDP & $\begin{array}{l}\text { Total dissolved phosphorus, total phosphorus filtered through a } \\
0.4 \text { micron filter }\end{array}$ \\
\hline SRP & Soluble reactive phosphorus \\
\hline TP & Total phosphorus, unfiltered, acidified with 1 Normal sulfuric acid \\
\hline TN & Total nitrogen, unfiltered \\
\hline SSC & Suspended sediment concentration \\
\hline
\end{tabular}


UNITS

\begin{tabular}{|c|c|}
\hline Variable & Units \\
\hline $\mathrm{pH}$ & $\mathrm{pH}$ units \\
\hline ANC & Microequivalents per liter \\
\hline Spec Cond & millisiemens \\
\hline Temp C & Water temperature in degrees Celsius \\
\hline $\mathrm{Ca}^{2+}$ & milligrams per liter \\
\hline $\mathrm{Mg}^{2+}$ & milligrams per liter \\
\hline $\mathrm{Na}^{+}$ & milligrams per liter \\
\hline $\mathrm{K}^{+}$ & milligrams per liter \\
\hline $\mathrm{NH}_{4}^{+}$ & milligrams per liter \\
\hline $\mathrm{Cl}^{-}$ & milligrams per liter \\
\hline $\mathrm{NO}_{3}^{-}$ & milligrams per liter \\
\hline $\mathrm{SO}_{4}{ }^{2-}$ & milligrams per liter \\
\hline $\mathrm{SiO}_{2}$ & milligrams per liter \\
\hline $\mathrm{DOC}$ & milligrams per liter \\
\hline $\mathrm{Al}$ & milligrams per liter \\
\hline Almono & milligrams per liter \\
\hline Alorg & milligrams per liter \\
\hline Altd & milligrams per liter \\
\hline TDP & milligrams per liter \\
\hline SRP & milligrams per liter \\
\hline $\mathrm{TP}$ & milligrams per liter \\
\hline $\mathrm{TN}$ & milligrams per liter \\
\hline Turbidity & nephelometric turbidity units (ntu) \\
\hline SSC & milligrams per liter \\
\hline
\end{tabular}




\title{
U.S. Geological Survey Catskill/Delaware Water-Quality Network: Water-Quality Report Water Year 2006
}

\author{
By Michael R. McHale and Jason Siemion
}

\section{Abstract}

The U.S. Geological Survey operates a 60-station streamgaging network in the New York City Catskill/Delaware Water Supply System. Water-quality samples were collected at 13 of the stations in the Catskill/Delaware streamgaging network to provide resource managers with water-quality and water-quantity data from the water-supply system that supplies about 85 percent of the water needed by the more than 9 million residents of New York City. This report summarizes water-quality data collected at those 13 stations plus one additional station operated as a part of the U.S. Environmental Protection Agency's Regional Long-Term Monitoring Network for the 2006 water year (October 1, 2005 to September 30, 2006). An average of 62 water-quality samples were collected at each station during the 2006 water year, including grab samples collected every other week and storm samples collected with automated samplers. On average, 8 storms were sampled at each station during the 2006 water year. The 2006 calendar year was the second warmest on record and the summer of 2006 was the wettest on record for the northeastern United States. A large storm on June 26-28, 2006, caused extensive flooding in the western part of the network where record peak flows were measured at several watersheds.

\section{Introduction}

The U.S. Geological Survey, in cooperation with the New York City Department of Environmental Protection (NYC-DEP) and other agencies, operates a network of 60 streamgaging stations throughout the New York City Catskill/Delaware Water Supply System. In 1997, 13 of those stations were selected for a water-quality network to provide water-quality data at sites throughout the Catskill/Delaware Water Supply System. The four main tasks associated with the network are (1) collect stream water-quality samples, (2) analyze the water chemistry of the samples, (3) make the water-quality data available to NYC-DEP, and (4) evaluate the effects of land use and land cover on the water quality of streams in the region, identify potential sources of contamination, and quantify trends in water quality throughout the network. Although data collection, laboratory analyses, and data dissemination to NYC-DEP are essential components of the project, the goal of the project is to quantify the effect of NYC-DEP's watershed management program on surfacewater quality and to determine the effects of land use on water quality in the region. The purpose of this report is to present data from 13 water-quality network stations and one Regional Long-Term Monitoring station in the Catskill/Delaware Water Supply System. The data were collected during water year 2006 (October 1, 2005, to September 30, 2006) and are presented in tables and hydrographs.

\section{Network Description}

The New York City Catskill/Delaware Water Supply System is located in the Catskill Mountains in southeastern New York (fig. 1). The system includes six surface-water reservoirs that supply about 85 percent of the drinking water to 9 million users in New York City. The streamgaging network is used to quantify the amount and the timing of water entering the reservoirs from different areas of the watershed. The water-quality network uses a nested design with small forested watersheds ("upper nodes") nested in larger multiple land use watersheds ("lower nodes"). The effect of land use on water quality can be assessed by examining differences in water quality between the upper and lower nodes as affected by the intervening land use. These data can also be used to investigate trends in water quality that are caused by changes in atmospheric deposition, climate, and land use. Waterquality stations are located in five of the six Catskill/Delaware reservoir watersheds.

\section{Schoharie Watershed}

Two water-quality stations are located on Batavia Kill which drains to Schoharie Creek about 3 mi upstream from the Schoharie Reservoir. The lower node station is Batavia Kill at Red Falls near Prattsville (USGS station number 01349950, site 1) and its corresponding upper node station is Batavia Kill 


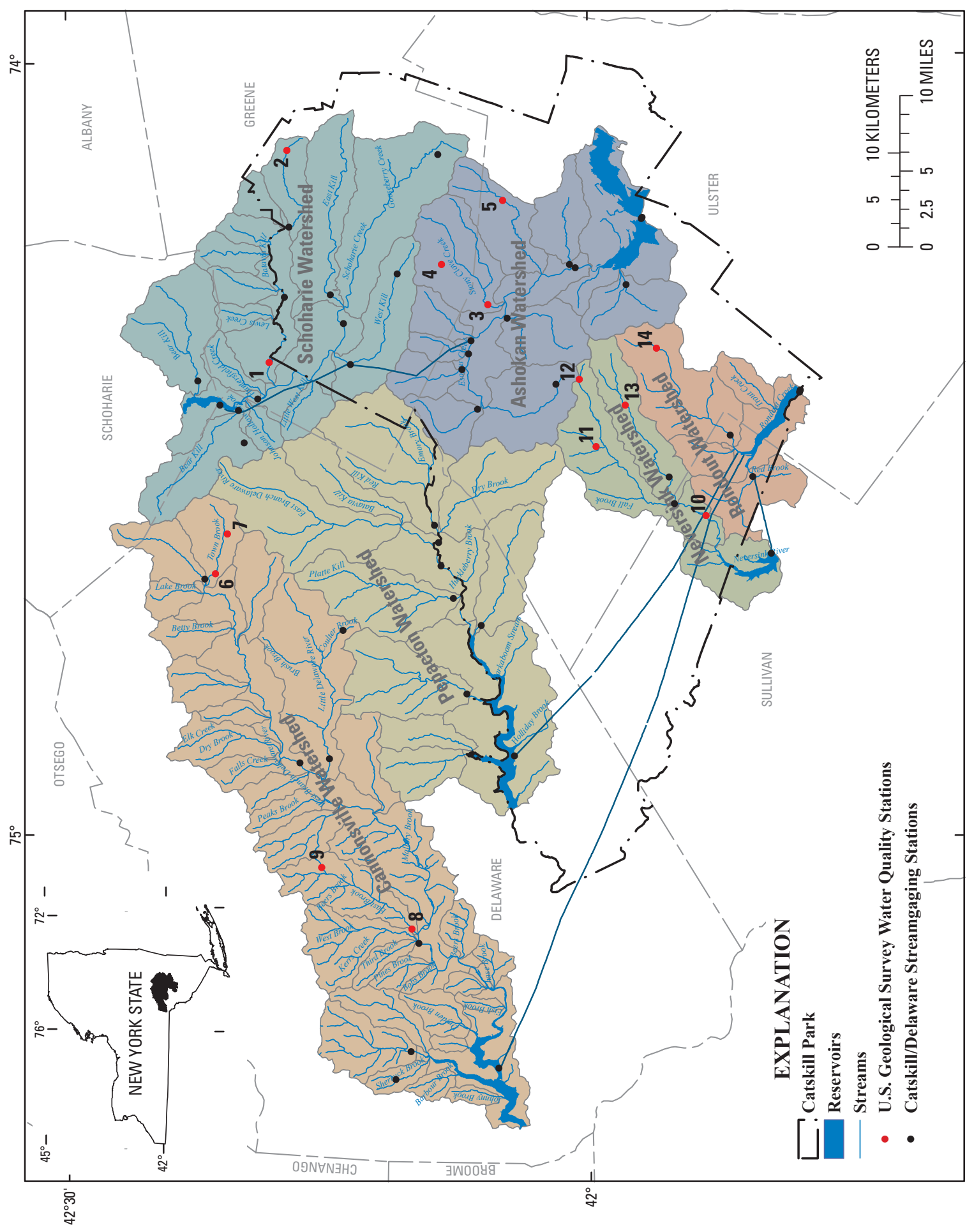

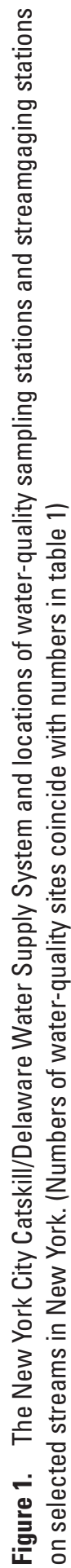


near Maplecrest (USGS station number 01349840, site 2). Batavia Kill near Red Falls (01349950) has been in operation since October 1997 and is located 2.2 mi southeast of Prattsville in Greene County, N.Y. The watershed is 80 percent forested, 19 percent agricultural, and 1 percent residential/ commercial (table 1), including the town of Windham, the Windham Ski Resort, and the Windham Country Club golf course. Batavia Kill near Maplecrest has also been in operation since October 1997 and is located 4.1 mi northeast of Maplecrest in Greene County, N.Y. Batavia Kill near Maplecrest watershed is 100 percent forested most of which is designated as New York State Forest Preserve.

\section{Ashokan Watershed}

There are three water-quality stations in the Ashokan Reservoir watershed. The lower node site is Stony Clove Creek near Phoenicia (USGS station number 01362380, site 3), its corresponding upper node site is Hollow Tree Brook at Lanesville (USGS station number 01362342, site 4), and the third site is Beaver Kill Tributary above Lake Hill (USGS station number 01362465, site 5) (fig. 1). The Stony Clove Creek station has been in operation since February 1997 and is located about $1.3 \mathrm{mi}$ upstream from Phoenicia in Ulster County and about $1.5 \mathrm{mi}$ upstream from the confluence of Stony Clove Creek and Esopus Creek. The watershed is 98 percent forested and although there are no towns or villages, residences are located throughout the watershed. A streambank stabilization and restoration program was completed in Stony Clove upstream from the station in 2005. The Hollow Tree Brook station has been in operation since October 1997 and is located 1 mi upstream from the confluence of Hollow Tree Brook and Stony Clove Creek in Greene County; the watershed is 100 percent forested. The Beaver Kill Tributary station is located in Ulster County about $1.2 \mathrm{mi}$ north of Lake Hill. There are a few residences located within the watershed, but it is 99 percent forested. The Beaver Kill Tributary station is not paired with any lower node station; the gage was added to the network in 2001 in anticipation of a forest harvesting project planned for the watershed. That project was never carried out, but the station provides data that can be compared to data from the Hollow Tree Brook watershed as a measure of the baseline water quality in the Ashokan Reservoir watershed. Water sampling at the Beaver Kill Tributary station was discontinued on September 30, 2006.

\section{Cannonsville Watershed}

There are four water-quality stations located in the Cannonsville Reservoir watershed. Two of the stations are located in the headwaters: Town Brook southeast of Hobart (USGS station number 01421618, site 6) and Town Brook Tributary (USGS station number 01421614, site 7). The Town Brook station, which has been in operation since October
1997, is located 1.4 mi upstream from the confluence of Town Brook and the West Branch Delaware River in Delaware County. The Town Brook watershed is 49 percent forested and 51 percent agricultural consisting of pasture, row crops, and hay associated with small family-owned dairy farms. There are many residences in the watershed, but no towns or villages. The Town Brook Tributary station is located $0.3 \mathrm{mi}$ upstream from the confluence with Town Brook and is 100 percent forested. There is evidence of past agricultural land use in the small watershed, but no farming has occurred for about 80 years. The remains of a small water-supply reservoir that has been completely silted-in is less than 100 yards downstream from the station on Town Brook Tributary.

Further down the West Branch Delaware River valley, East Brook enters the West Branch Delaware River in the Village of Walton in Delaware County. There are two waterquality stations in the East Brook watershed: East Brook east of Walton (USGS station number 01422747, site 8) and Wolf Creek at Mundale (USGS station number 01422738, site 9). The East Brook station, which has been in operation since October 1998, is located $0.55 \mathrm{mi}$ upstream from the mouth of the stream, and within the Village of Walton. The watershed is 54 percent forested and 45 percent agricultural land use; most of the agricultural land is used for pasture and grassland. The Wolf Creek watershed is located in the headwaters of East Brook; it is 75 percent forested and 24 percent agricultural land use. Wolf Creek is the only upper node station with more than 3 percent agricultural land use (table 1). The station is located $8 \mathrm{mi}$ northeast of Walton, about $0.3 \mathrm{mi}$ from the mouth of Wolf Creek.

\section{Pepacton Watershed}

There were no water-quality stations in the Pepacton Reservoir watershed during the 2006 water year.

\section{Neversink Watershed}

There are 4 water-quality stations in the Neversink Reservoir watershed —one lower node station, Neversink River near Claryville (USGS station number 01435000, site 10), and 3 upper node stations, Biscuit Brook above Pigeon Brook (USGS station number 01434025, site 11), West Branch Neversink River at Winnisook Lake (USGS station number 01434021, site 12) (referred to hereafter as the Winnisook station), and East Branch Neversink River northeast of Denning (USGS station number 0143400680, site 13) (referred to hereafter as the Tisons station). The Neversink River station has been in operation since 1937 and is located $2.2 \mathrm{mi}$ downstream from the confluence of the East and West Branches and about 3.2 mi upstream from the Neversink reservoir. The Neversink River watershed is 98 percent forested and includes a few residences and a 6,000 acre residential camping, environmental education, and conference center. All of the upper node watersheds are 
Table 1. Characteristics for water-quality stations in or associated with the U.S. Geological Survey Catskill/Delaware Water Quality Network in the Catskill Mountains, New York.

[Land-use percentages were calculated using the 1992 National Land Cover Dataset. Site ID corresponds to locations in figure 1. USGS, U.S. Geological Survey; $\mathrm{mi}^{2}$, square miles; $\mathrm{ft}$, feet]

\begin{tabular}{|c|c|c|c|c|c|c|c|c|c|}
\hline \multirow{2}{*}{$\begin{array}{l}\text { Site } \\
\text { ID }\end{array}$} & \multirow{2}{*}{ Station name } & \multirow{2}{*}{$\begin{array}{l}\text { USGS gag- } \\
\text { ing station } \\
\text { number }\end{array}$} & \multirow{2}{*}{ Latitude } & \multirow{2}{*}{ Longitude } & \multirow{2}{*}{$\begin{array}{l}\text { Area } \\
\left(\mathrm{mi}^{2}\right)\end{array}$} & \multirow{2}{*}{$\begin{array}{l}\text { Elevation } \\
\quad(\mathrm{ft})\end{array}$} & \multicolumn{3}{|c|}{$\begin{array}{l}\text { Land use } \\
\text { (in percent) }\end{array}$} \\
\hline & & & & & & & Forest & $\begin{array}{l}\text { Agricul- } \\
\text { ture }\end{array}$ & $\begin{array}{l}\text { Residen- } \\
\text { tial }\end{array}$ \\
\hline 1 & Batavia Kill at Red Falls & 01349950 & $42^{\circ} 18^{\prime} 30^{\prime \prime}$ & $74^{\circ} 23^{\prime} 25^{\prime \prime}$ & 68.6 & 1,260 & 80 & 19 & 1 \\
\hline 2 & Batavia Kill near Maplecrest & 01349840 & $42^{\circ} 17^{\prime} 22^{\prime \prime}$ & $74^{\circ} 06^{\prime} 59^{\prime \prime}$ & 2.03 & 2,160 & 100 & 0 & 0 \\
\hline 3 & Stony Clove near Phoenicia & 01362380 & $42^{\circ} 05^{\prime} 53^{\prime \prime}$ & $74^{\circ} 19^{\prime} 03^{\prime \prime}$ & 31.5 & 900 & 98 & 1 & 1 \\
\hline 4 & Hollow Tree Brook at Lanesville & 01362342 & $42^{\circ} 08^{\prime} 32^{\prime \prime}$ & $74^{\circ} 15^{\prime} 55^{\prime \prime}$ & 1.95 & 1,480 & 99 & 1 & 0 \\
\hline 5 & $\begin{array}{l}\text { Beaver Kill Tributary above } \\
\text { Lake Hill }\end{array}$ & 01362465 & $42^{\circ} 04^{\prime} 59^{\prime \prime}$ & $74^{\circ} 10^{\prime} 59^{\prime \prime}$ & 0.98 & 1,300 & 99 & 0 & 1 \\
\hline 6 & Town Brook southeast of Hobart & 01421618 & $42^{\circ} 21^{\prime} 40^{\prime \prime}$ & $74^{\circ} 39^{\prime} 45^{\prime \prime}$ & 14.3 & 1,670 & 49 & 51 & 0 \\
\hline 7 & Town Brook Tributary & 01421614 & $42^{\circ} 20^{\prime} 58^{\prime \prime}$ & $74^{\circ} 36^{\prime} 41^{\prime \prime}$ & 0.76 & 1,900 & 97 & 3 & 0 \\
\hline 8 & East Brook east of Walton & 01422747 & $42^{\circ} 10^{\prime} 22^{\prime \prime}$ & $75^{\circ} 07^{\prime} 18^{\prime \prime}$ & 24.7 & 1,240 & 54 & 45 & 1 \\
\hline 9 & Wolf Creek at Mundale & 01422738 & $42^{\circ} 15^{\prime} 34^{\prime \prime}$ & $75^{\circ} 02^{\prime} 32^{\prime \prime}$ & 0.61 & 1,760 & 75 & 24 & 1 \\
\hline 10 & Neversink River at Claryville & 01435000 & $41^{\circ} 53^{\prime} 24^{\prime \prime}$ & $74^{\circ} 35^{\prime} 25^{\prime \prime}$ & 66.6 & 1,522 & 98 & 1 & 1 \\
\hline 11 & $\begin{array}{l}\text { Biscuit Brook above Pigeon } \\
\text { Brook at Frost Valley }\end{array}$ & 01434025 & $41^{\circ} 59^{\prime} 43^{\prime \prime}$ & $74^{\circ} 30^{\prime} 05^{\prime \prime}$ & 3.72 & 2,060 & 100 & 0 & 0 \\
\hline 12 & $\begin{array}{l}\text { West Branch Neversink River at } \\
\text { Winnisook Lake }\end{array}$ & 01434021 & $42^{\circ} 00^{\prime} 40^{\prime \prime}$ & $74^{\circ} 24^{\prime} 53^{\prime \prime}$ & 0.77 & 2,680 & 100 & 0 & 0 \\
\hline 13 & $\begin{array}{l}\text { East Branch Neversink River } \\
\text { northeast of Denning }\end{array}$ & 0143400680 & $41^{\circ} 58^{\prime} 01^{\prime \prime}$ & $74^{\circ} 26^{\prime} 54^{\prime \prime}$ & 8.93 & 2,140 & 100 & 0 & 0 \\
\hline 14 & $\begin{array}{l}\text { Rondout Creek above Red Brook } \\
\text { at Peekamoose }\end{array}$ & 01364959 & $41^{\circ} 56^{\prime} 13^{\prime \prime}$ & $74^{\circ} 22^{\prime} 30^{\prime \prime}$ & 5.36 & 1,740 & 100 & 0 & 0 \\
\hline
\end{tabular}

100 percent forested. The Biscuit Brook station has been in operation since 1983 and is located within the 6,000 acre residential camping complex, $0.6 \mathrm{mi}$ upstream of the mouth of the brook (fig. 1). The Winnisook station, which has been in operation since 1991, is located on the West Branch Neversink River about 4.5 mi northeast of the Biscuit Brook station. This station measures drainage from the north face of Slide Mountain, the highest peak in the Catskill Mountains. The Tisons watershed drains the headwaters of the East Branch Neversink River, including the southern slopes of Slide Mountain. The station has been in operation since 1990 and is located 9.6 mi upstream from the confluence of the East and West Branches.

The Neversink watershed is the only watershed in the network that has multiple upper node stations associated with one lower node station. The Neversink watershed has been a focus of acid rain research since the early 1980s and is the most acidic of the West-of-Hudson reservoir streams. The three upper node stations in the Neversink watershed also are part of the Long-Term Monitoring (LTM) network operated by the USGS, in cooperation with the U.S. Environmental Protection Agency (USEPA). Data from the LTM network are used to measure changes in stream-water quality in response to reductions in acidic deposition as a result of the Title IV amendment of the Clean Air Act. The additional data collected for the LTM network are added to the data collected for the Catskill/Delaware Water Quality Network. As a result, baseline water-quality data in the Neversink watershed have been well characterized, and trends in water quality caused by trends in atmospheric deposition or changes in the climate are well documented. Wet-only atmospheric deposition is collected at a U.S. Geological Survey National Atmospheric Deposition Program (NADP) collector located $0.14 \mathrm{mi}$ from the Biscuit Brook station. Samples are collected weekly and shipped to the NADP Central Analytical Laboratory in Champaign, Ill., for analyses of major ions. These data are available through the National Atmospheric Deposition Program website: http://nadp.sws.uiuc.edu/. 


\section{Rondout Watershed}

No sites in the Catskill/Delaware network are located in the Rondout Reservoir watershed; however, one station in the watershed is part of the LTM network. Rondout Creek above Red Brook at Peekamoose (USGS station number 01364959, site 14) is located 0.8 mi upstream from the outlet of Peekamoose Lake and has been in operation since 1996. The watershed is 100 percent forested and is located on New York State Forest Preserve land. The Rondout Creek station is included in this report because it is typically included in interpretations of network data. The sampling strategy at this site is similar to the strategy at sites in the Catskill/Delaware Water-Quality Network and the water-quality analyses are almost identical.

\section{Climate Summary}

During the 2006 calendar year the average annual temperature for the contiguous United States was $54.9^{\circ} \mathrm{F}$, the second warmest on record (1895 to 2006) (National Climatic Data Center (NCDC), 2007). The annual temperature in New York State was classified as "much above normal" during 2006 (NCDC, 2007). At the Slide Mountain meteorological station within the Neversink watershed the 30 -year mean annual temperature was $41.3^{\circ} \mathrm{F}$ from 1971 to 2000 , and the mean for 2006 was $44.4^{\circ} \mathrm{F}$. In 2006 , the northeastern United States had the wettest summer recorded, and the annual precipitation was considered "much above normal" (NCDC, 2007). Precipitation totaled 69.1 in. at Slide Mountain (fig. 1) during 2006 and 108.5 in. of snow fell during the winter of 2005-06.

\section{Methods}

This section presents a description of the field, laboratory, and statistical methods used for this study. Water-quality samples were collected at each site every other week and during storms, for an average 8 storms per site and 62 samples per site.

\section{Field Methods}

All water-quality sampling and field data collection were conducted by USGS personnel using standard USGS data collection protocols (USGS, variously dated). Field data collection was separated into two categories, streamflow data collection and water-quality data collection. Stream stage was recorded at 15-minute intervals using a datalogger and discharge measurements were made at 8 week intervals and during high flow. Stage-discharge relations were developed for each site to compute the discharge. A sampling hydrograph was drafted for each site showing the stream-flow hydrograph and the date and time each sample was collected.

Water-quality samples were collected every 2 weeks at each site. The sites were divided into two groups - a western field trip and an eastern field trip; the two field trips were completed on the same day whenever possible. Grab samples were collected in 1 liter acid-washed polypropelene bottles from the center of the channel whenever possible or from the streambank. The bottles were rinsed 3 times with streamwater, filled, and stored on ice until delivered to the laboratory in Troy, N.Y., where samples were refrigerated at $4^{\circ} \mathrm{C}$ until analyzed. Each site was equipped with a stage-activated automated sampler which collected water-quality samples during storms and winter thaws. Whenever possible automated samples were retrieved and processed within 24 hours of collection, though there were times when some samples were processed as long as 48 hours after collection. Field quality assurance and quality control were assessed through collection of triplicate samples and blanks.

\section{Laboratory Methods}

Streamwater samples were chilled at $4^{\circ} \mathrm{C}$ until analysis by ion chromatography for $\mathrm{Cl}^{-}, \mathrm{SO}_{4}^{2-}$, and $\mathrm{NO}_{3}^{-}$. Inductively coupled plasma-optical emission spectrometry was used for $\mathrm{Ca}^{2+}, \mathrm{Mg}^{2+}, \mathrm{SiO}_{2}$, and total dissolved $\mathrm{Al}$ (Altd), and atomic absorption spectrophotometry for $\mathrm{Na}^{+}$and $\mathrm{K}^{+}$(Lawrence and others, 1995). Dissolved organic carbon (DOC) was analyzed with a Dohrmann carbon analyzer. A pH electrode was used to determine $\mathrm{pH}$, and an auto-titrator was used to determine ANC (acid neutralizing capacity) (Lawrence and others, 1995). Speciated Al was determined by complexation with pyrocatechol violet, according to a two-channel flow injection method (Henshaw and others, 1988). The first channel yields total monomeric $\mathrm{Al}$ (Almono) on an untreated aliquot, and the second channel yields organic monomeric $\mathrm{Al}$ (Alorg) after the sample passes through a cation exchange resin. All phosphorus fractions were analyzed at the USGS National Water Quality Laboratory in Denver, Colo. Total phosphorus aliquots were acidified with 1 milliliter of $4.5 \mathrm{~N}$ sulfuric acid and analyzed using semi-automated colorimetry. Total dissolved phosphorus and orthophosphate (soluble reactive phosphorus) were filtered through 0.4-micron polycarbonate filters and analyzed using colorimetry (Fishman, 1993). DOC samples were filtered through nominal 0.7 -micron glass fiber filters prior to analysis. Sample aliquots for major cations $\left(\mathrm{Ca}^{2+}, \mathrm{Mg}^{2+}, \mathrm{Na}^{+}\right.$, and $\left.\mathrm{K}^{+}\right)$, major anions $\left(\mathrm{Cl}^{-}, \mathrm{SO}_{4}^{2-}\right.$, and $\left.\mathrm{NO}_{3}^{-}\right)$, and aluminum species (Altd, Almono, and Alorg) were filtered through 0.4-micron polycarbonate filters prior to analysis.

Laboratory activities were subjected to the quality assurance and control procedures of the USGS Watershed Research Program which has been reviewed by the USEPA Office of Research and Development. The laboratory qualityassurance program includes quality-control samples, sample blanks, blind-audit samples, and sample triplicates. A detailed 
description of the laboratory quality-assurance program can be found in the laboratory quality-assurance reports (Lincoln and others, 2006a and b).

\section{Statistical Methods}

Summary statistics were calculated for each water-quality parameter. For solutes that included censored values (values below the limit of quantification-TP, TDP, SRP, and SSC) means and medians were estimated. For less than 50 percent censored values the Kaplan-Meier statistic was used, but only the median was calculated because the lowest values were censored which causes the mean calculated by the KaplanMeier statistic to be biased high (Helsel, 2005). For 50 to 80 percent censored data maximum likelihood estimation was used (Helsel, 2005). For sites with greater than 80 percent censored values, no summary statistics were calculated indicated as $\mathrm{NC}$ in the summary statistics tables. 


\section{Water-Quality Station Summary}




\section{HUDSON RIVER BASIN}

\section{BATAVIA KILL NEAR MAPLECREST, NY}

LOCATION. lat. 42 17'22", long. 74 06'59", Greene County, Hydrologic Unit 02020005, on left bank off County Route 56, 4.1 mi northeast of Maplecrest.

DRAINAGE AREA. $2.03 \mathrm{mi}^{2}$.

\section{WATER-DISCHARGE RECORDS}

PERIOD OF RECORD. October 1997 to September 2006.

GAGE. Water-stage recorder and crest-stage gage. Elevation of gage is 2,160 ft above sea level, from topographic map.

\section{WATER-QUALITY RECORDS}

PERIOD OF RECORD. October 1997 to September 2006.

REMARKS. There were 60 samples collected during the 2006 water year. Seven storms were sampled with 1-7 samples collected per storm. Acid neutralizing capacity reached a period of record high concentration at a discharge of $0.46 \mathrm{ft}^{3} / \mathrm{s}$ prior to a storm in early October 2005. Turbidity reached a period of record high concentration at a discharge of $18.4 \mathrm{ft}^{3} / \mathrm{s}$ during a storm in early October 2005 . Soluble reactive phosphorus reached a period of record high on August 8, 2006, at a flow of $0.47 \mathrm{ft}^{3} / \mathrm{s}$.

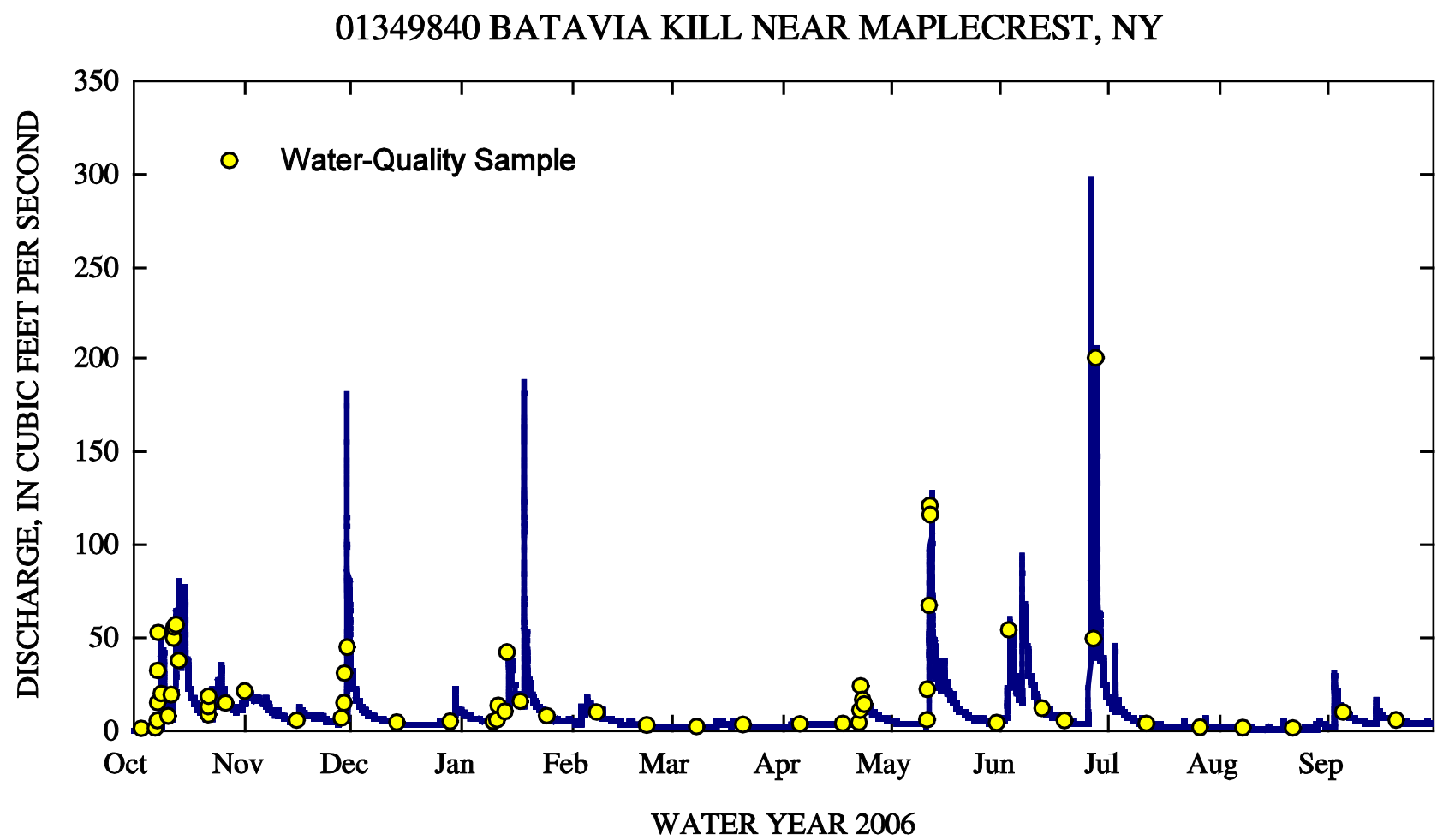


矛

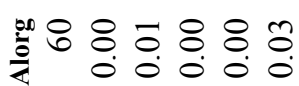

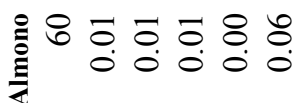

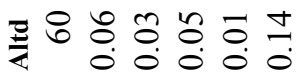

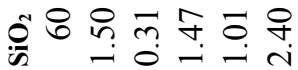

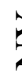

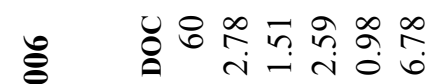

(1)

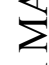

兵

$\exists$

$\varangle \quad$

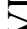

芯

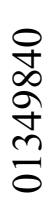
i் 8

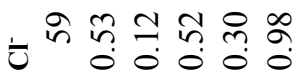
뉸 \& \& \& \& \& + চ Z +

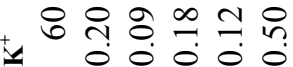

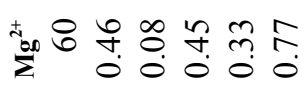

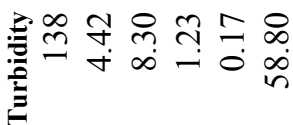

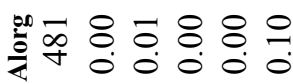

高市

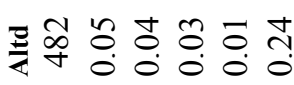

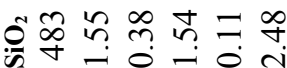

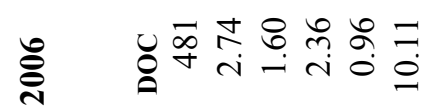
ปَ 芕它 을

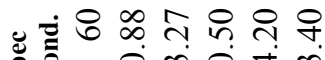
ते $\mathrm{N}-m$

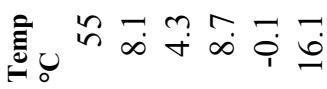
=
సं ப

는

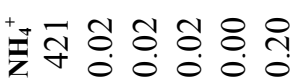

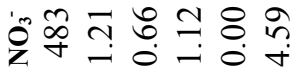
Z⿱艹

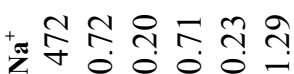

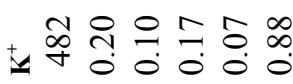

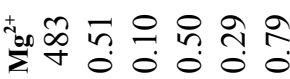

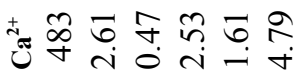

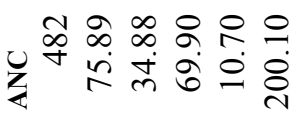

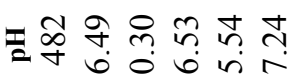

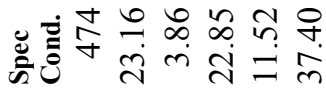

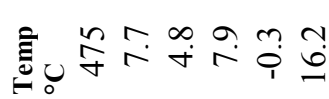

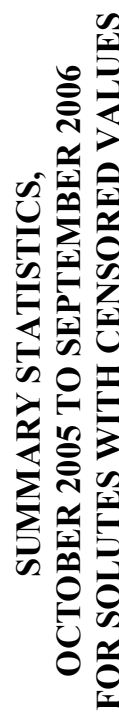

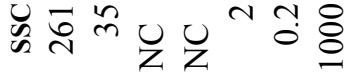

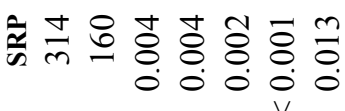
空全 फी

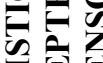

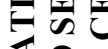
的记 え会

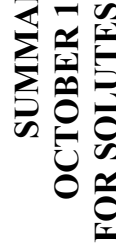

囩

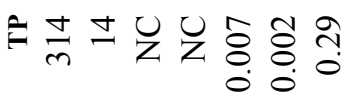
$\checkmark$

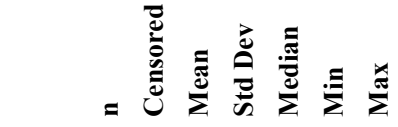




\section{HUDSON RIVER BASIN}

\section{BATAVIA KILL AT RED FALLS NEAR PRATTSVILLE, NY}

LOCATION. lat. $42^{\circ} 18^{\prime} 30^{\prime \prime}$, long. $74^{\circ} 23^{\prime} 25^{\prime \prime}$, Greene County, Hydrologic Unit 02020005, on right bank $200 \mathrm{ft}$ southwest of State Highway 23 at Red Falls, 1.9 mi upstream from mouth, and 2.2 mi southeast of Prattsville.

DRAINAGE AREA. $68.6 \mathrm{mi}^{2}$.

\section{WATER-DISCHARGE RECORDS}

PERIOD OF RECORD. October 1997 to September 2006.

GAGE. Water-stage recorder and crest-stage gage. Elevation of gage is $1,260 \mathrm{ft}$ above sea level, from topographic map.

\section{WATER-QUALITY RECORDS}

PERIOD OF RECORD. October 1999 to September 2006.

REMARKS. There were 60 samples collected during the 2006 water year. Nine storms were sampled with 1-7 samples collected per storm. $\mathrm{SO}_{4}$ reached a period of record high concentration at a discharge of $203 \mathrm{ft}^{3} / \mathrm{s}$ during a storm in early October 2005 . On the rising limb of a secondary peak of the same storm SRP and TDP also reached period of record high concentrations at a discharge of $330 \mathrm{ft}^{3} / \mathrm{s}$.

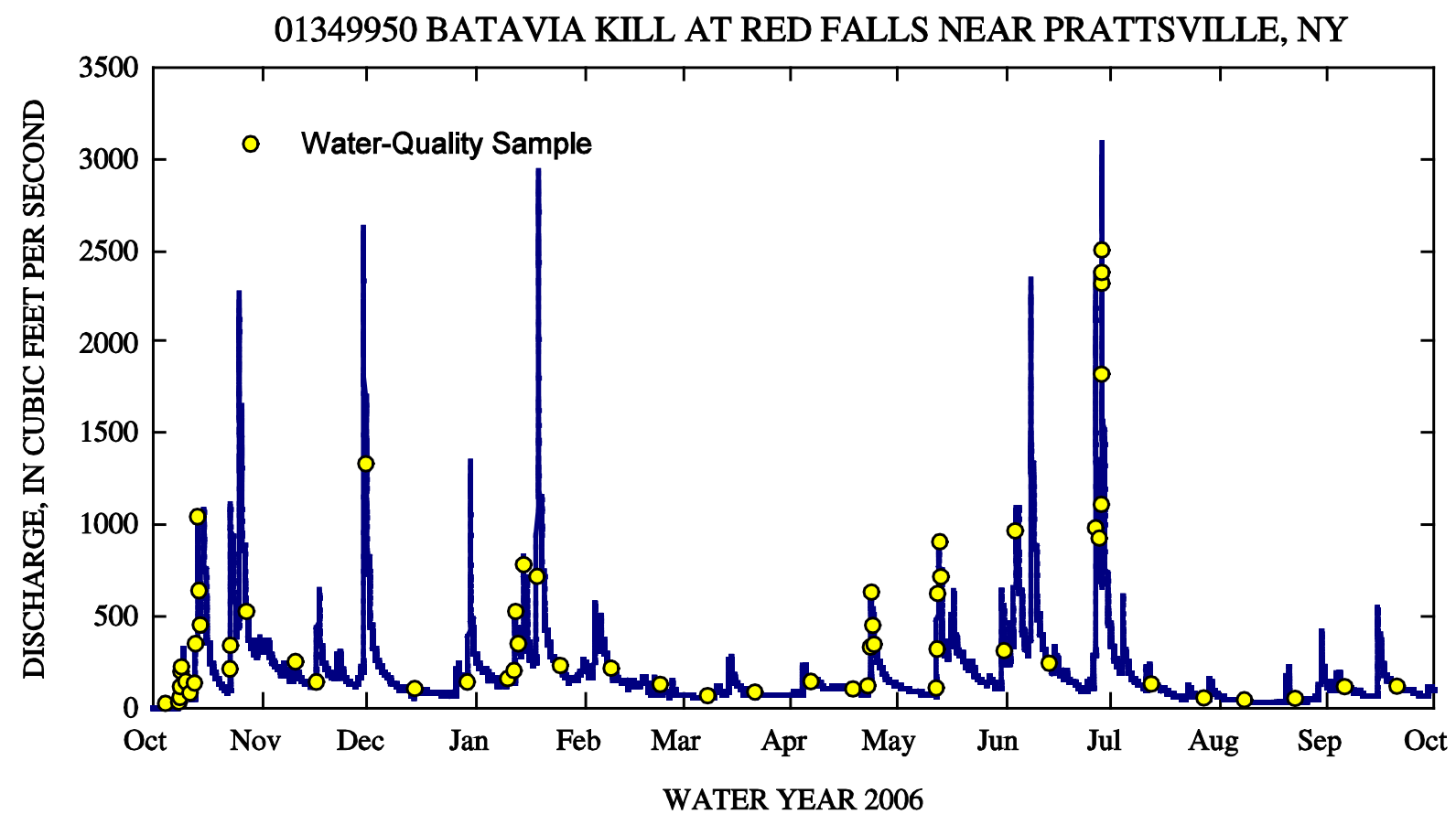




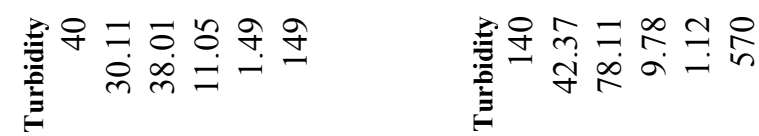

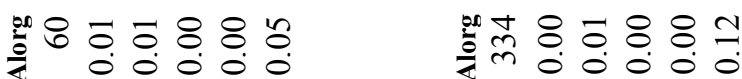

:

产

छ

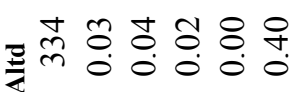

융

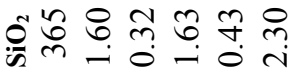

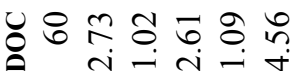

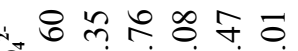

o

ที ㅊำ

- ป 느ำ

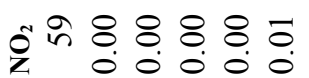

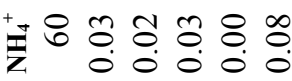

గొ

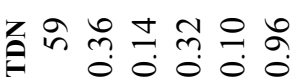

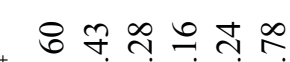

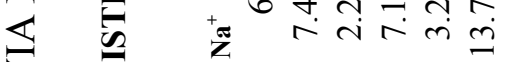

$\underset{⿱ ㇒}{\mathbb{E}}$

ํำ

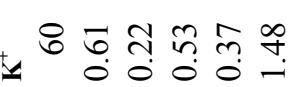

too

- $-\dot{0}-\dot{0} \pi$

ปึ

윰

i

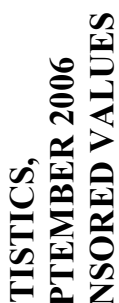

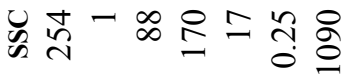

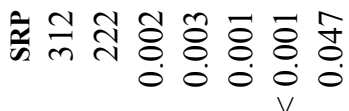

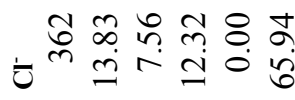

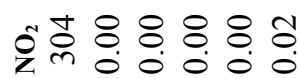

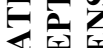

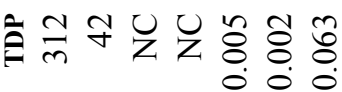

is

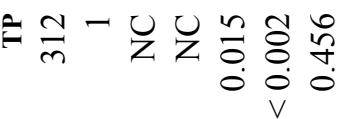

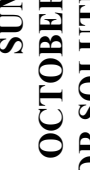

+t

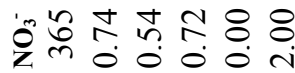

Zूล

+

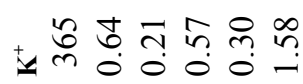

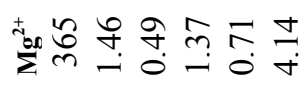

热

$8 \sigma m ? \pm t$

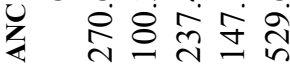

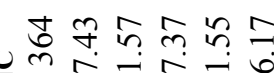

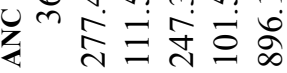

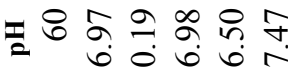

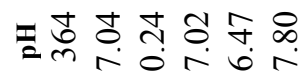

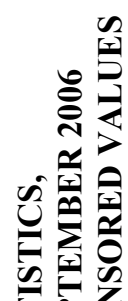

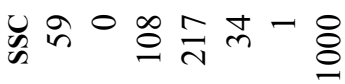

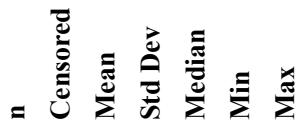

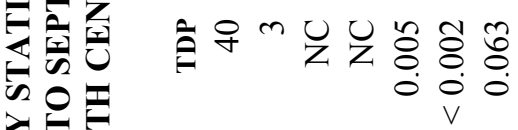

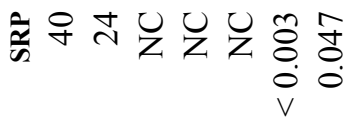

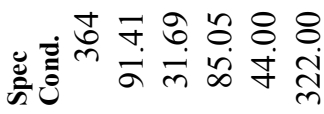

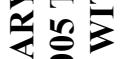

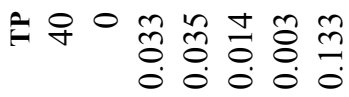

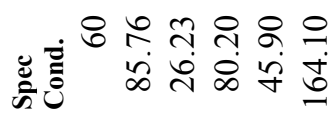

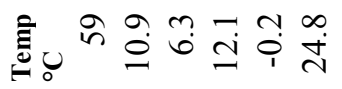

产

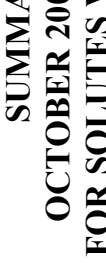

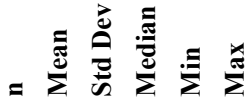




\section{HUDSON RIVER BASIN}

\section{HOLLOW TREE BROOK AT LANESVILLE, NY}

LOCATION. lat. $42^{\circ} 08^{\prime} 32^{\prime \prime}$, long. $74^{\circ} 15^{\prime} 55^{\prime \prime}$, Greene County, Hydrologic Unit 02020006, on left bank downstream from bridge on Diamond Notch Road, about 1.0 mi upstream from mouth, and 1.0 mi north of Lanesville.

DRAINAGE AREA. $1.95 \mathrm{mi}^{2}$.

\section{WATER-DISCHARGE RECORDS}

PERIOD OF RECORD. October 1997 to September 2006.

GAGE. Water-stage recorder and crest-stage gage. Elevation of gage is $1,480 \mathrm{ft}$ above sea level, from topographic map.

\section{WATER-QUALITY RECORDS}

PERIOD OF RECORD. October 1997 to September 2006.

REMARKS. There were 60 samples collected during the 2006 water year. Seven storms were sampled with 2-9 samples collected per storm. Specific conductance, $\mathrm{Ca}^{2+}$, TDN, and $\mathrm{NO}_{3}{ }^{-}$ reached period of record high concentrations during a storm in early October 2005. Turbidity and TP reached period of record high concentrations during a large storm in late November 2005.

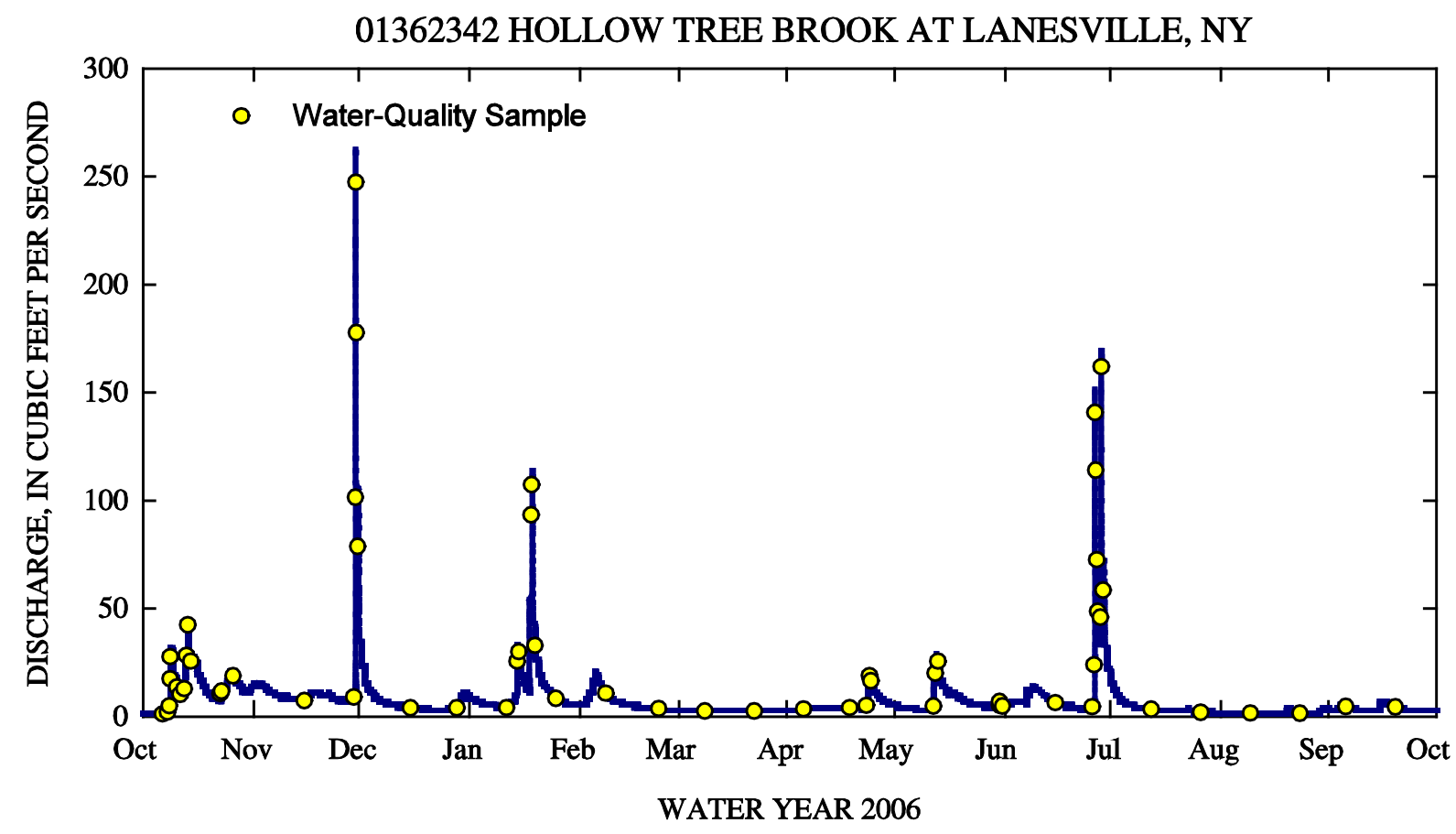




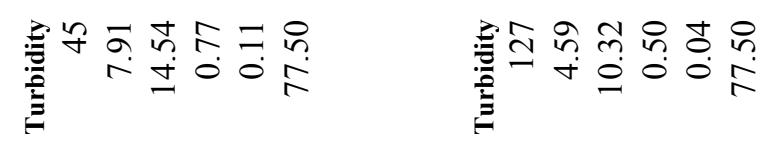

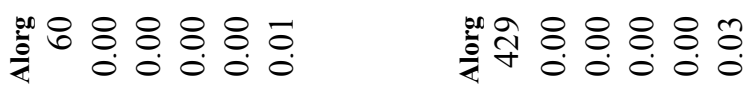

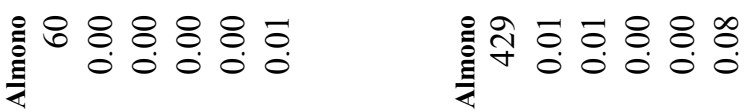

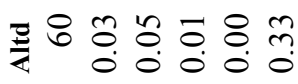

छ

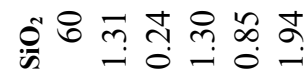

ஸ̆

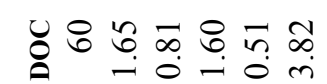

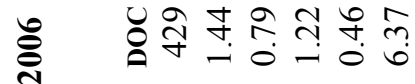

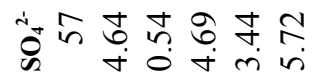

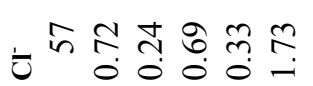

ㄴำ $888=$

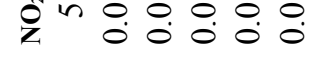

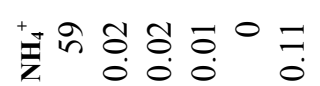

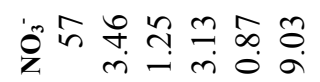

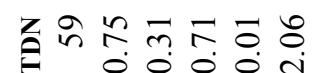

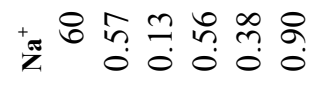

ะ

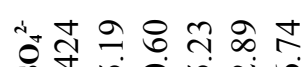

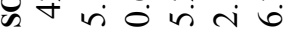

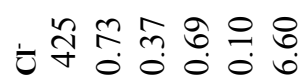

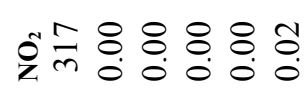

स

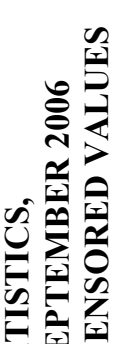

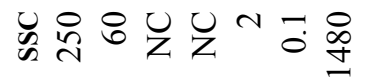

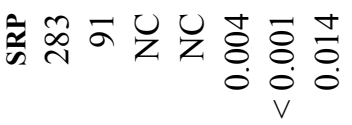

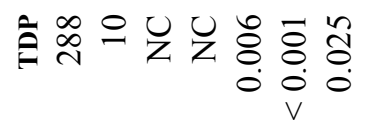

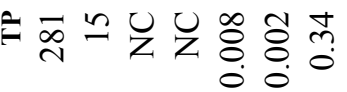

方至

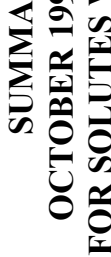

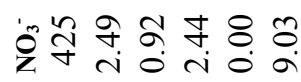

zสิ

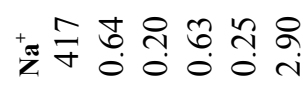

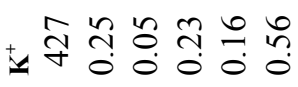

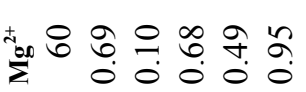

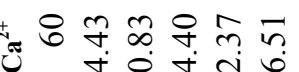

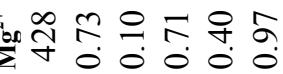

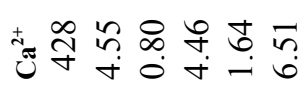

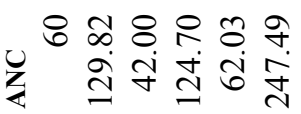

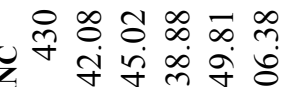

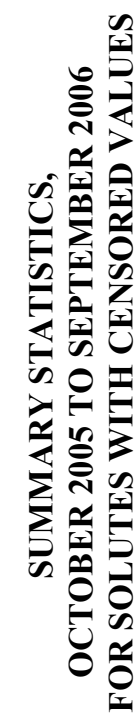

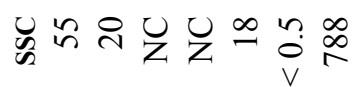

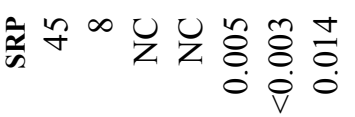

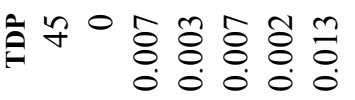

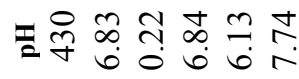

을 $\underset{0}{0} \frac{\infty}{0}$ :

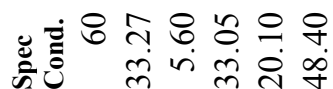

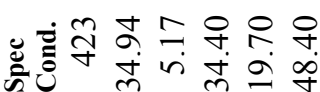

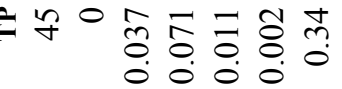

言

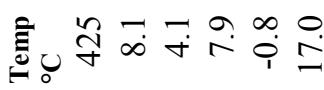

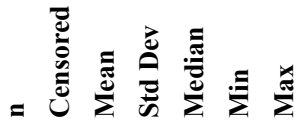




\section{HUDSON RIVER BASIN}

\section{STONY CLOVE CREEK NEAR PHOENICIA, NY}

LOCATION. lat. $42^{\circ} 05^{\prime} 53^{\prime \prime}$, long. $74^{\circ} 19^{\prime} 03^{\prime \prime}$, Ulster County, Hydrologic Unit 02020006, on left bank 0.5 mi south of Chichester on State Highway 214, and 1.3 mi upstream from mouth.

DRAINAGE AREA. $31.5 \mathrm{mi}^{2}$.

\section{WATER-DISCHARGE RECORDS}

PERIOD OF RECORD. December 1996 to January 1997 (annual maximum only), February 1997 to September 2006.

REVISED RECORDS. WDR NY-99-1: 1997 (P), 1998 (P).

GAGE. Water-stage recorder and crest-stage gage. Elevation of gage is $900 \mathrm{ft}$ above sea level, from topographic map.

\section{WATER-QUALITY RECORDS}

PERIOD OF RECORD. October 1999 to September 2006.

REMARKS. There were 62 samples collected during the 2006 water year. Eight storms were sampled with 3-8 samples collected per storm. Total dissolved nitrogen, $\mathrm{NO}_{3}^{-}$, Almono, and Alorg reached period of record high concentrations during a storm in early October 2005. Ammonium and turbidity reached period of record high concentrations at a discharge of $5,564 \mathrm{ft}^{3} / \mathrm{s}$ during a storm in late June 2006 .

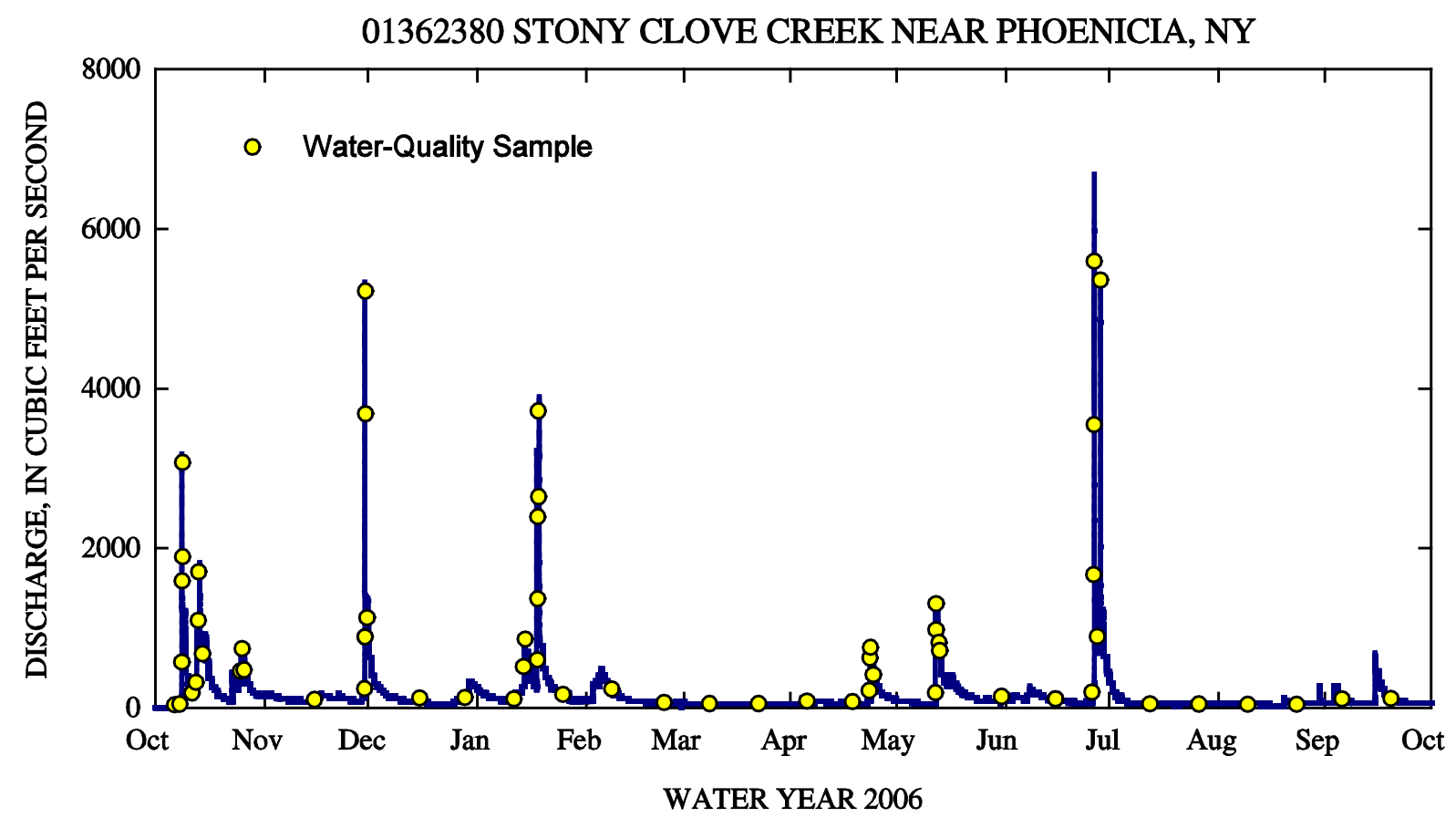




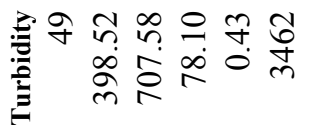

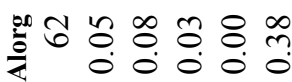

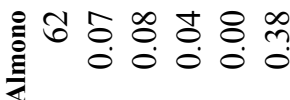

列

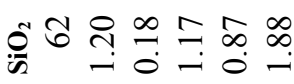

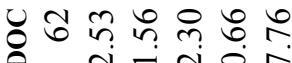

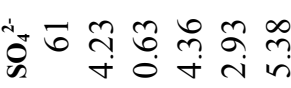

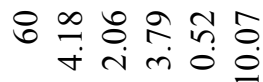

ง

+

'ं

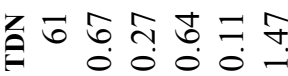

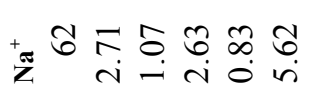

진 는

$\checkmark 00000$

莎

‡َ

ชิ ชิ

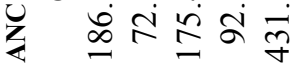

ॠ

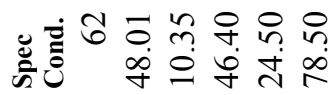

言

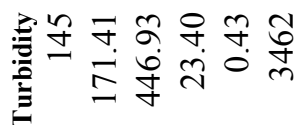

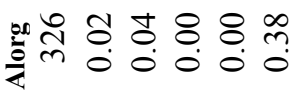

音

छ

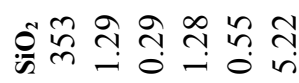

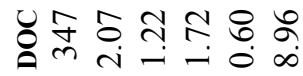

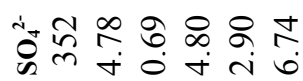

ப

๘

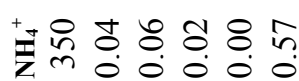

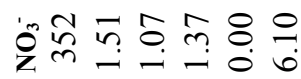

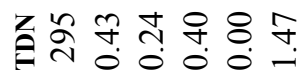

+

姈

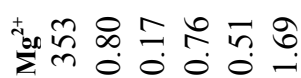

ปึ

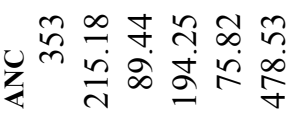

ฐ

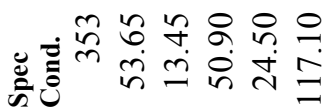

继

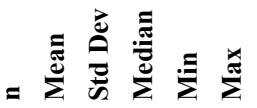
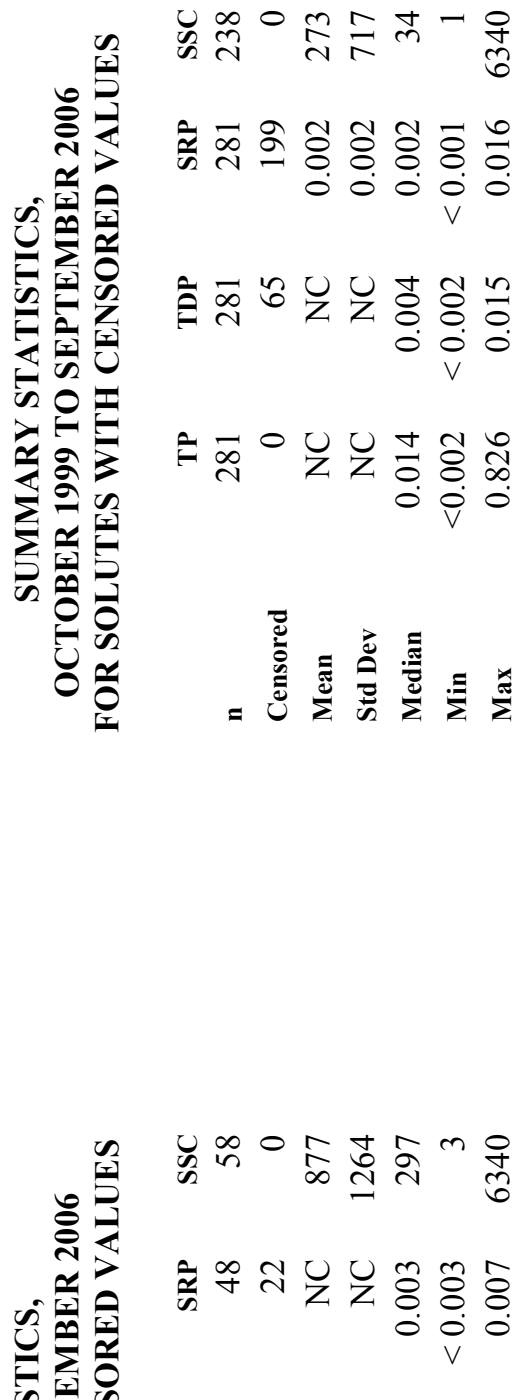

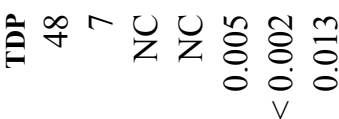

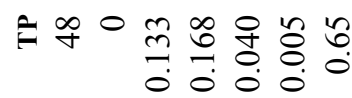

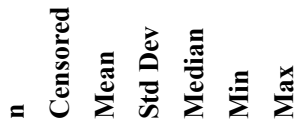




\section{DELAWARE RIVER BASIN}

\section{TOWN BROOK TRIBUTARY SOUTHEAST OF HOBART, NY}

LOCATION. lat. 42 20'58', long. 74 36'41", Delaware County, Hydrologic Unit 02040101, on left bank 0.3 mi upstream from mouth, and $3.3 \mathrm{mi}$ southeast of Hobart.

DRAINAGE AREA. $0.76 \mathrm{mi}^{2}$.

\section{WATER-DISCHARGE RECORDS}

PERIOD OF RECORD. October 1998 to September 2006.

GAGE. Water-stage recorder and crest-stage gage. Supplementary water-stage recorder about $15 \mathrm{ft}$ upstream used for low-flow periods. Elevation of gage is 1,900 ft above sea level, from topographic map.

\section{WATER-QUALITY RECORDS}

PERIOD OF RECORD. September 1998 to September 2006.

REMARKS. There were 60 samples collected during the 2006 water year. Seven storms were sampled with 2-6 samples collected per storm. Monomeric aluminum, Alorg, and turbidity reached period of record high concentrations at a discharge of $2.48 \mathrm{ft}^{3} / \mathrm{s}$ during a small storm in late May 2006. During the 2006 water year a timber stand improvement was carried out on Town of Hobart land within the Town Brook Tributary watershed for commercial sale and to thin the trees to promote forest growth.

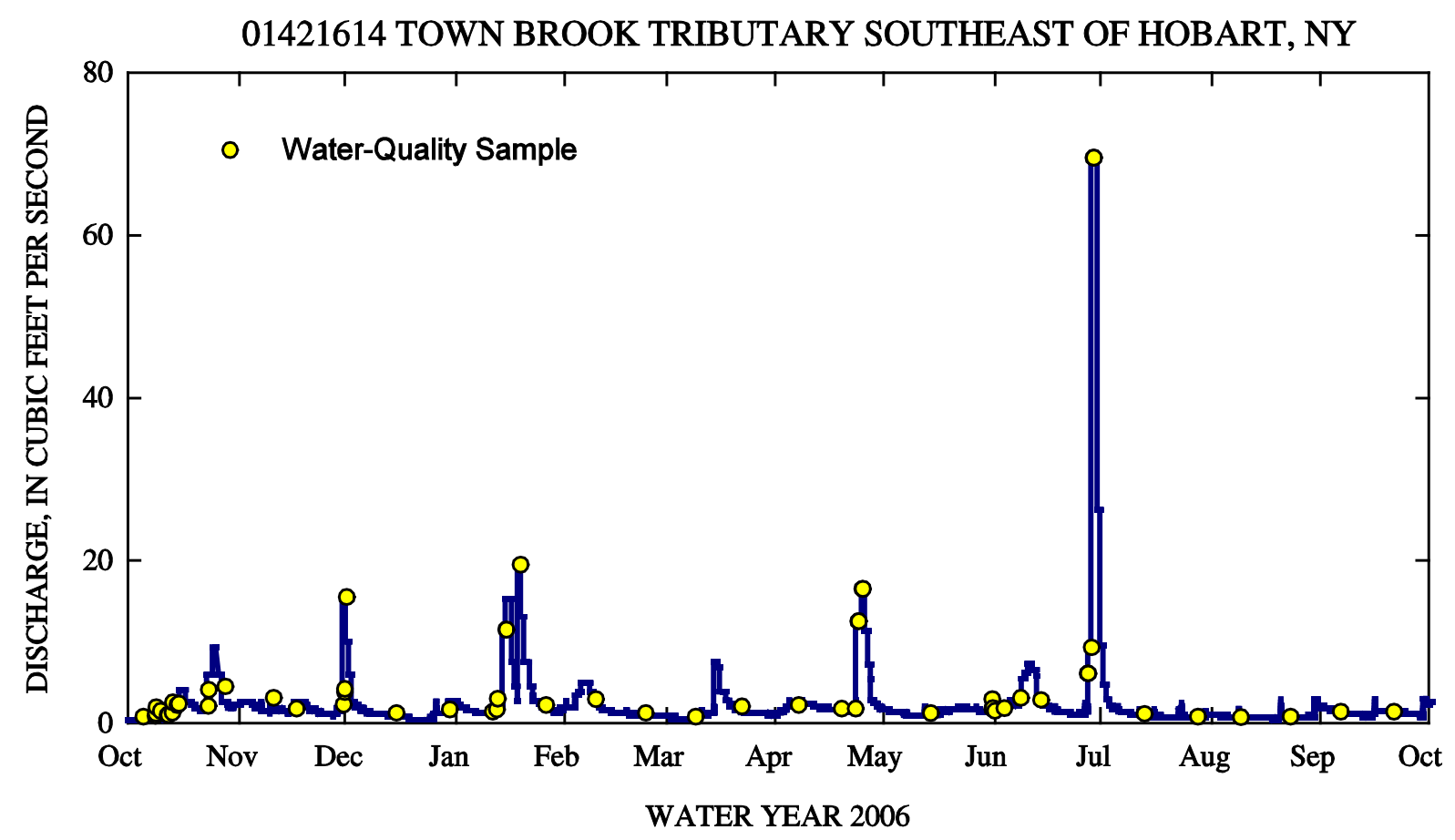




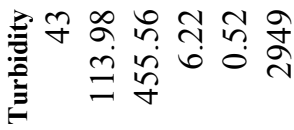

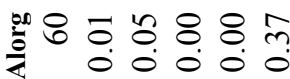

$\begin{array}{llllll}8 & 1 & n & 8 & 8 & \infty \\ \vdots & 0 & 0 & 0 & 0 & 0\end{array}$

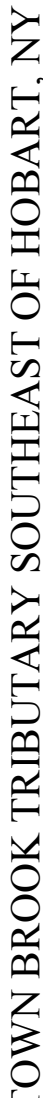

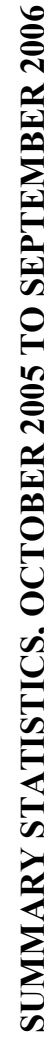

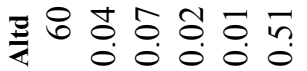

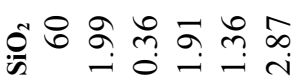

○ 8 후 $\infty$ ڤ

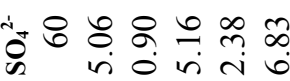

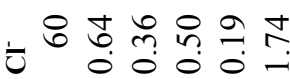

ঠั

+

z 000000

గొ

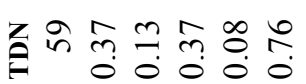

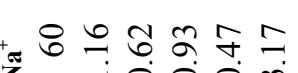

z $-\dot{0} 0 \dot{0}$

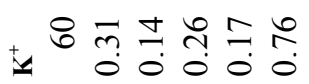

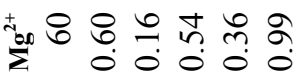

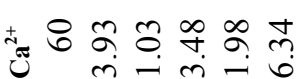

8 के तุ फे

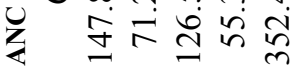

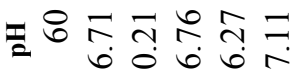

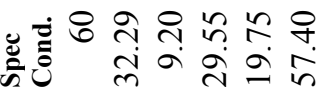

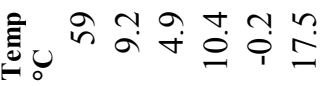

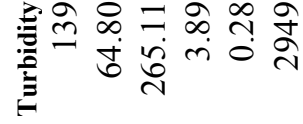

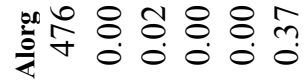

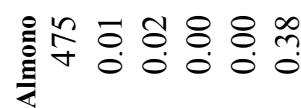

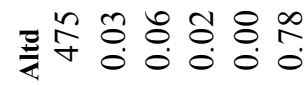

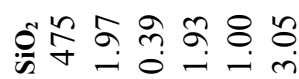

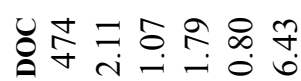

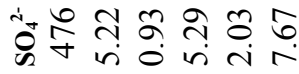

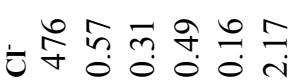

గ

芒筞

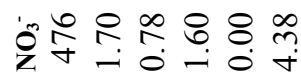

z

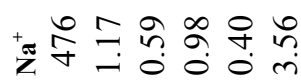

考守

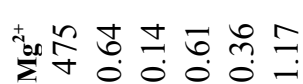

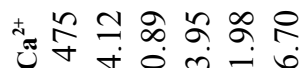

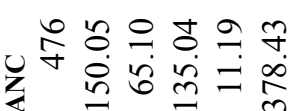

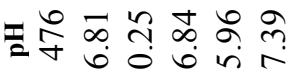

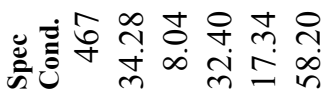

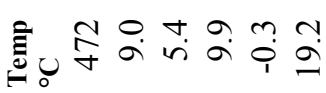

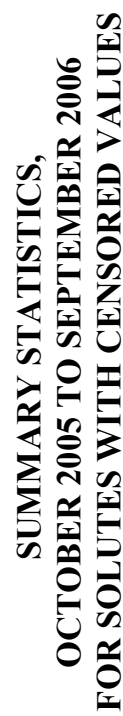

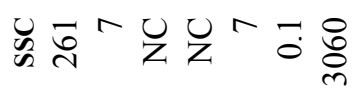

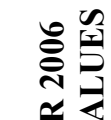

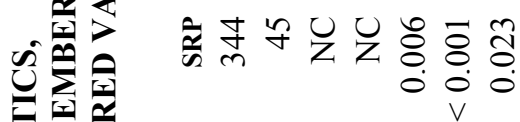

象

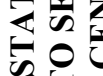

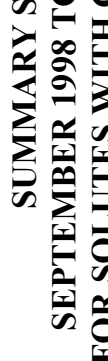

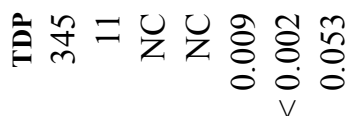

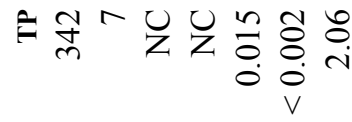

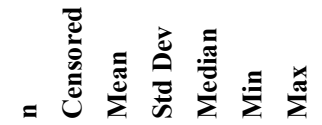

= 


\section{DELAWARE RIVER BASIN}

\section{TOWN BROOK SOUTHEAST OF HOBART, NY}

LOCATION. lat. $42^{\circ} 21^{\prime} 40^{\prime \prime}$, long. $74^{\circ} 39^{\prime} 45^{\prime \prime}$, Delaware County, Hydrologic Unit 02040101, on left bank $10 \mathrm{ft}$ downstream from bridge on Clove Road, 0.9 mi southeast of Hobart, and $1.4 \mathrm{mi}$ upstream from mouth.

DRAINAGE AREA. $14.3 \mathrm{mi}^{2}$.

\section{WATER-DISCHARGE RECORDS}

PERIOD OF RECORD. October 1997 to September 2006.

GAGE. Water-stage recorder and crest-stage gage. Elevation of gage is $1,670 \mathrm{ft}$ above sea level, from topographic map.

\section{WATER-QUALITY RECORDS}

PERIOD OF RECORD. January 1999 to September 2006.

REMARKS. There were 61 samples collected during the 2006 water year. Nine storms were sampled with 1-7 samples collected per storm. $\mathrm{SO}_{4}$ reached a period of record high concentration a discharge of $9.71 \mathrm{ft}^{3} / \mathrm{s}$ during low flow in early October 2005. Monomeric aluminum, Alorg, and SSC reached period of record high concentrations during a storm in late June at a discharge of $2,096 \mathrm{ft}^{3} / \mathrm{s}$.

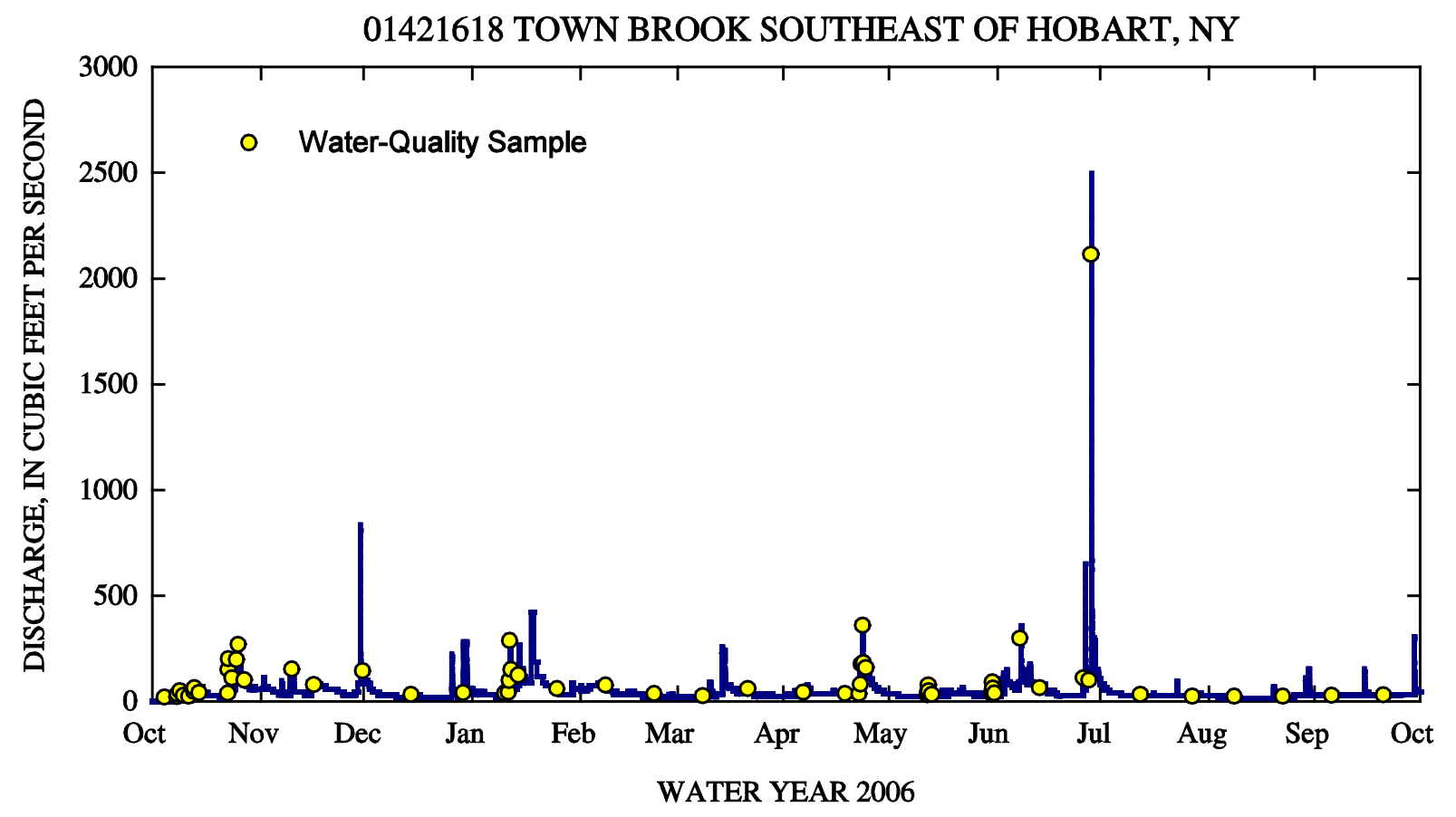




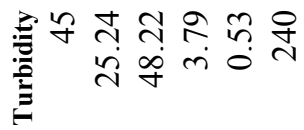

荘

ڤ

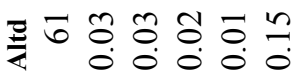

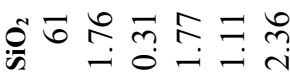

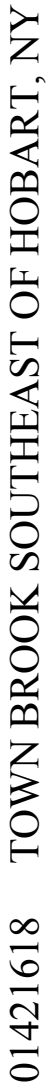

i. $\overline{0}$ กิ

б쥬에

- 0 in

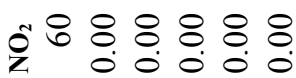

t"

గ

ไี่ กิก กิ์

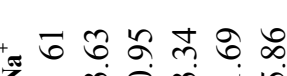

๙

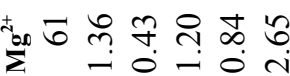

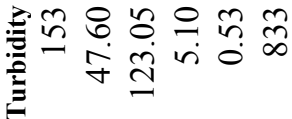

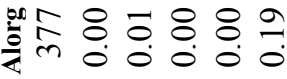

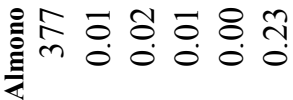

列命

ํํำ

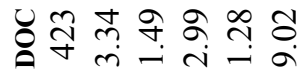

यें के मे

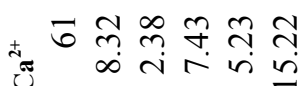

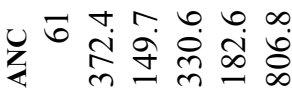

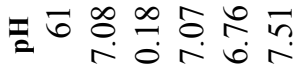

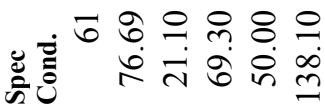

言 $0 \stackrel{0}{0}$

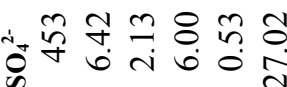

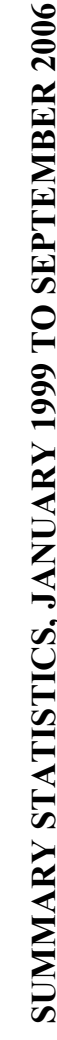

ப一

テñ

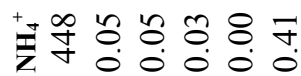

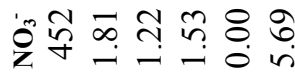

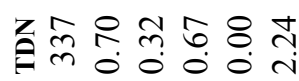

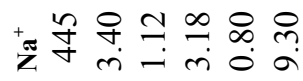

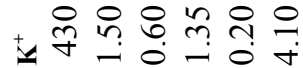

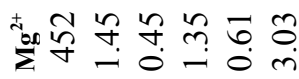

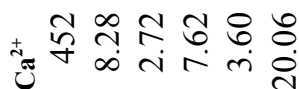

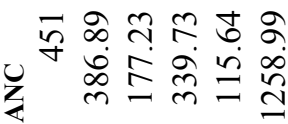

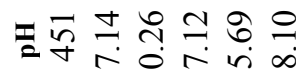

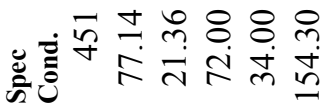

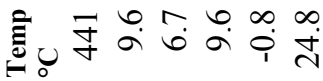

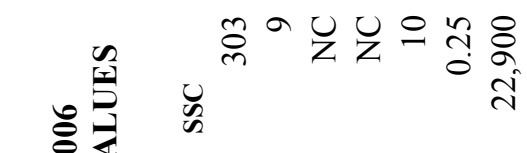

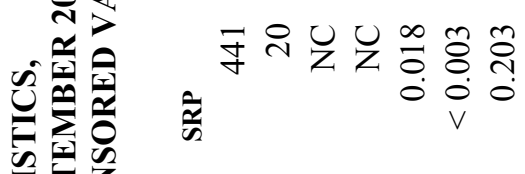

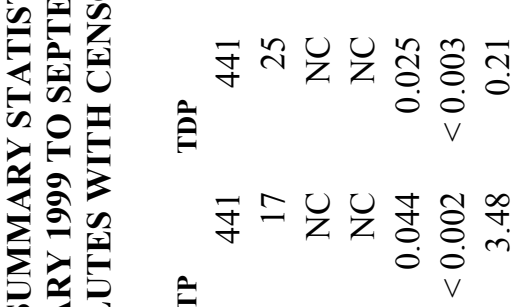

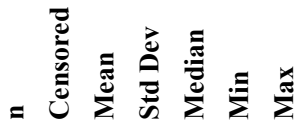

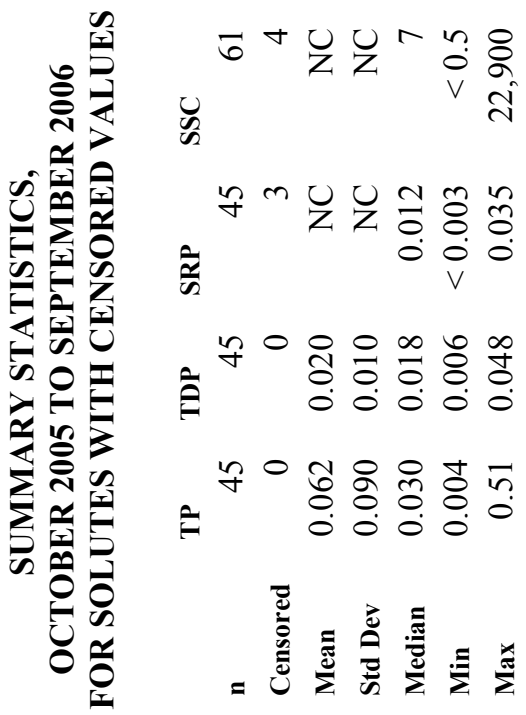




\section{DELAWARE RIVER BASIN}

\section{WOLF CREEK AT MUNDALE, NY}

LOCATION. lat. 42 15'34", long. 75 02'32", Delaware County, Hydrologic Unit 02040101, on left bank $6 \mathrm{ft}$ downstream from culvert on Munn Road, and $8 \mathrm{mi}$ northeast of Walton.

DRAINAGE AREA. $0.61 \mathrm{mi}^{2}$.

\section{WATER-DISCHARGE RECORDS}

PERIOD OF RECORD. October 1998 to September 2006.

GAGE. Water-stage recorder and crest-stage gage. Elevation of gage is 1,760 ft above sea level, from topographic map.

\section{WATER-QUALITY RECORDS}

PERIOD OF RECORD. October 1999 to September 2006.

REMARKS. There were 60 samples collected during the 2006 water year. Five storms were sampled with 1-11 samples collected per storm. Specific conductance, $\mathrm{ANC}, \mathrm{Cl}^{-}, \mathrm{SO}_{4}{ }^{2-}$, and $\mathrm{SiO}_{2}$ reached period of record high concentrations during a small storm in early October 2005. Monomeric aluminum, Alorg, TDP, and SRP reached period of record high concentrations during a large storm that occurred from June 26-28, 2006. This storm produced a period of record peak discharge of $350 \mathrm{ft}^{3} / \mathrm{s}$ on June 28,2006 . Sodium reached a period of record high concentration on June 7,2006 , and $\mathrm{K}^{+}$reached a period of record high concentration on August 19, 2006.

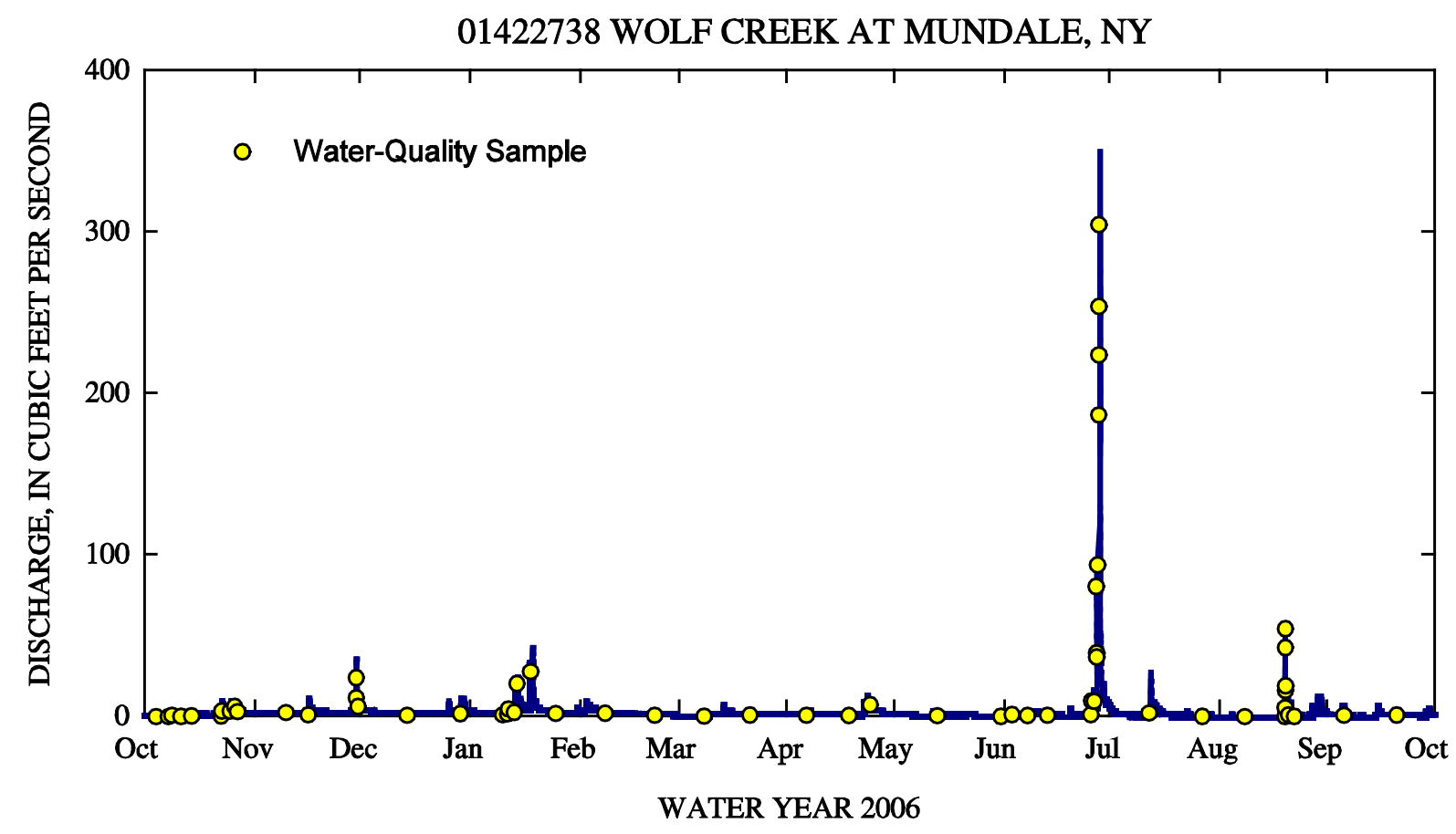




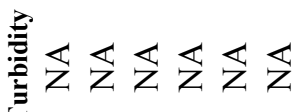

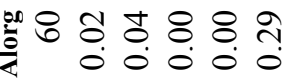

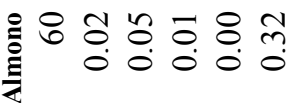

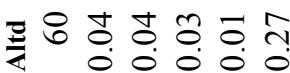

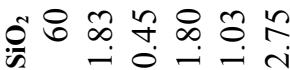



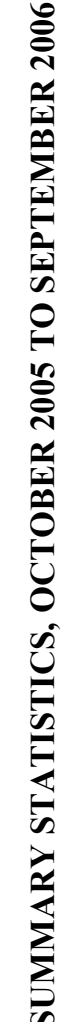

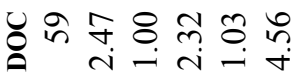

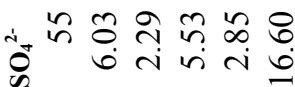

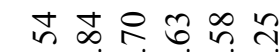

उ 4 irton

ఫึ

tच की

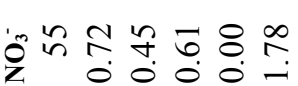

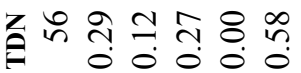

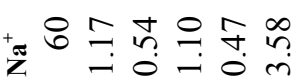

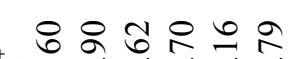

$\simeq \quad 00004$

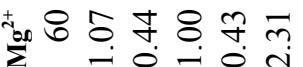

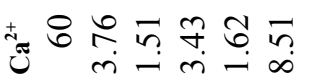

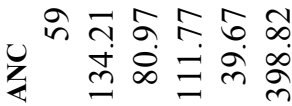

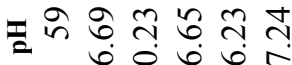

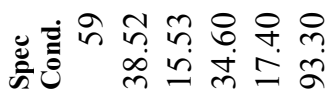

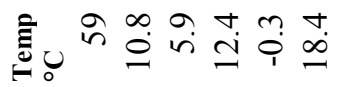

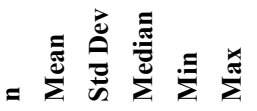

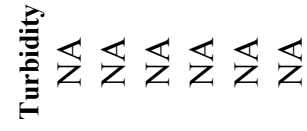

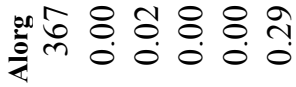

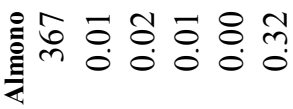

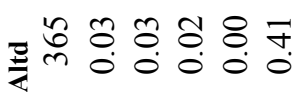

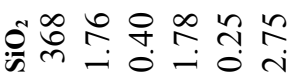

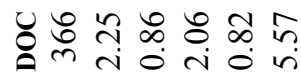

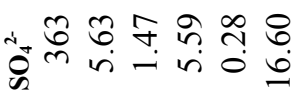

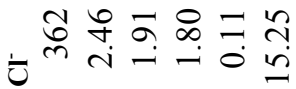

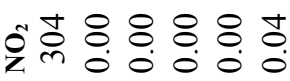

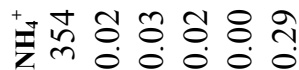

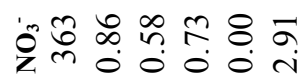

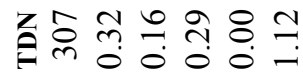

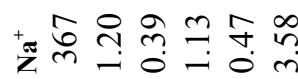

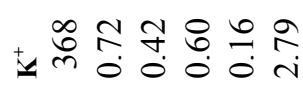

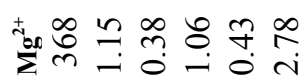

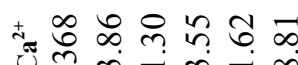

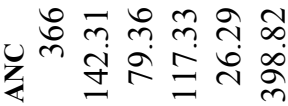

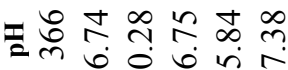

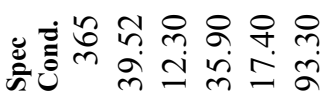

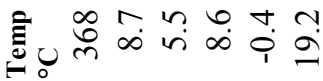

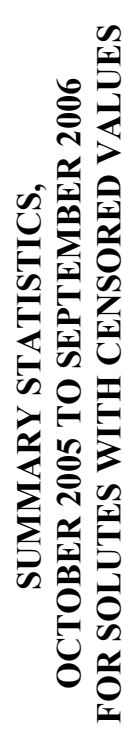

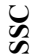

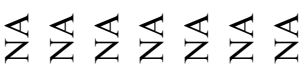

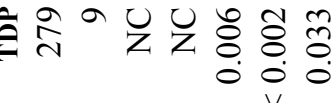

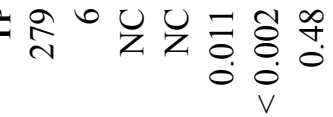

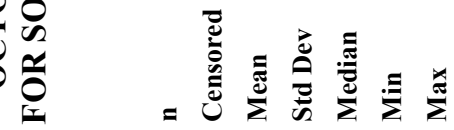

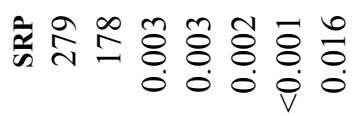

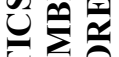

武明

氠氛

in

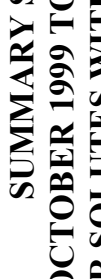

응

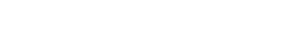




\section{DELAWARE RIVER BASIN}

\section{EAST BROOK EAST OF WALTON, NY}

LOCATION. lat. $42^{\circ} 10^{\prime} 22^{\prime \prime}$, long. $75^{\circ} 07^{\prime} 18^{\prime \prime}$, Delaware County, Hydrologic Unit 02040101, on right bank $150 \mathrm{ft}$ downstream from bridge on East Street, in Walton, and 0.55 mi upstream from mouth (at West Branch Delaware River).

DRAINAGE AREA. $24.7 \mathrm{mi}^{2}$.

\section{WATER-DISCHARGE RECORDS}

PERIOD OF RECORD. October 1998 to September 2006.

GAGE. Water-stage recorder and crest-stage gage. Elevation of gage is $1,240 \mathrm{ft}$ above sea level, from topographic map.

\section{WATER-QUALITY RECORDS}

PERIOD OF RECORD. October 1999 to September 2006.

REMARKS. There were 57 samples collected during the 2006 water year. Five storms were sampled with 4-6 samples collected per storm. Sulfate reached a period of record high concentration at a discharge of $23 \mathrm{ft}^{3} / \mathrm{s}$ during low flow in mid-October 2005 . Total phosphorus, Altd, Almono, and Alorg reached period of record high concentrations during a large storm that produced a period of record peak discharge of $7,110 \mathrm{ft}^{3} / \mathrm{s}$ on June 28, 2006. ANC reached a period of record high concentration at a discharge of $15 \mathrm{ft}^{3} / \mathrm{s}$ during low flow in early August 2006.

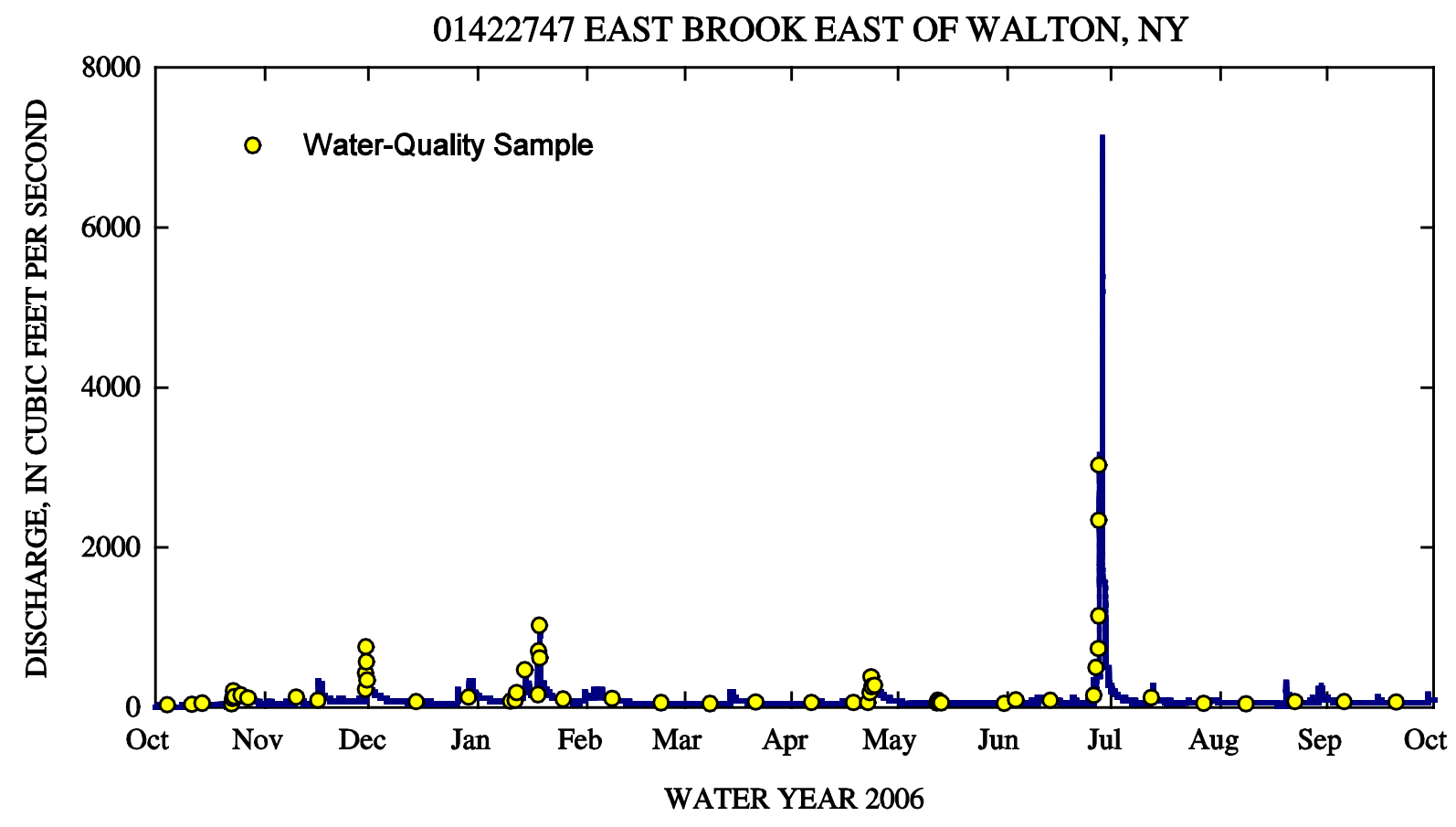




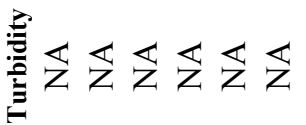

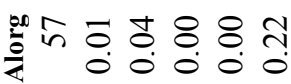

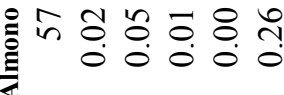

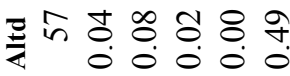

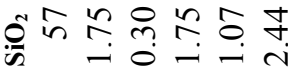

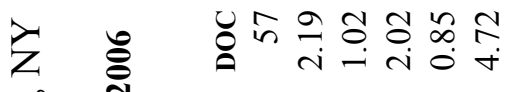

2
3
0
3
0
0
5
4
4
4
0
0
0
0
0
0

旁

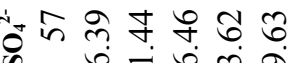

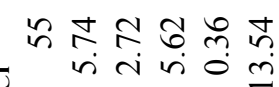

응 8.880

2

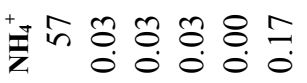

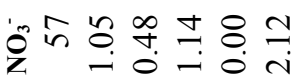

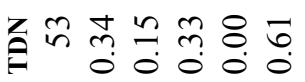

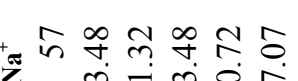

in $\infty \tilde{m}^{\infty} \infty$

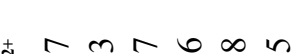

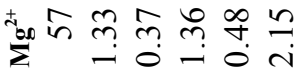

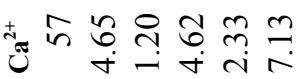

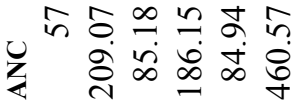

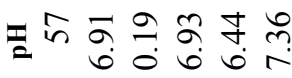

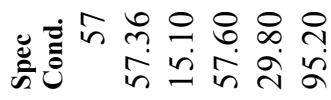

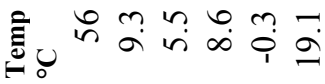

=

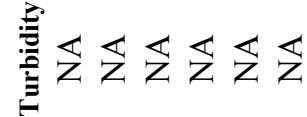

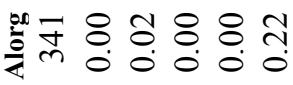

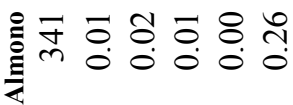

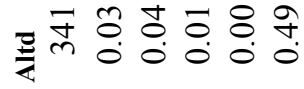

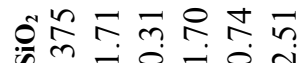

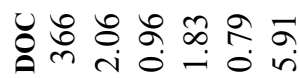

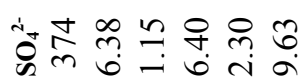

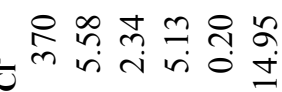

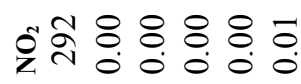

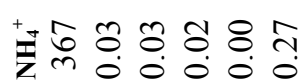

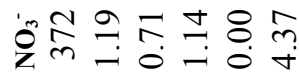

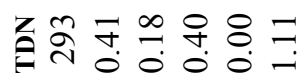

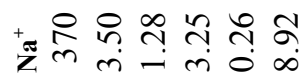

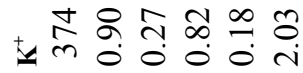

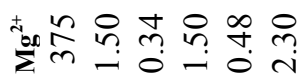

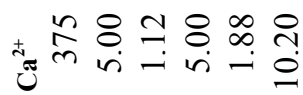

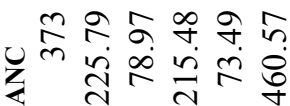

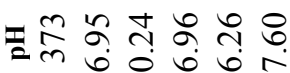

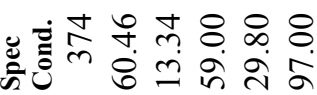

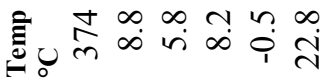

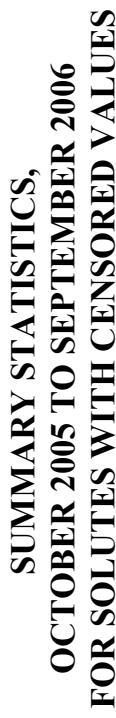

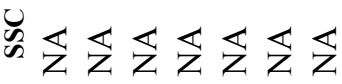

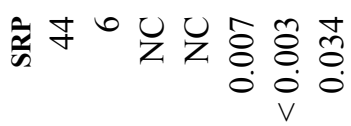

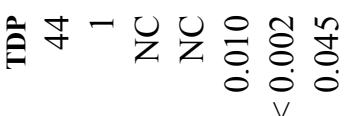

•

When

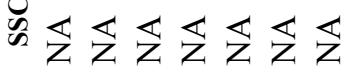

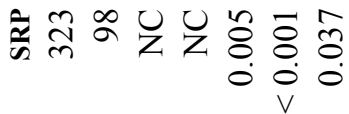

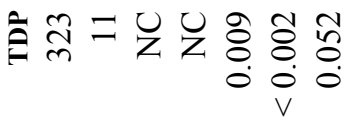

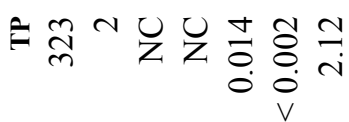

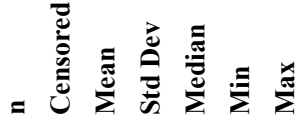




\section{DELAWARE RIVER BASIN}

\section{BISCUIT BROOK ABOVE PIGEON BROOK AT FROST VALLEY, NY}

LOCATION. lat. $41^{\circ}$ 59'43", long. 74 30'05", Ulster County, Hydrologic Unit 02040104, on right bank 0.2 mi upstream from Pigeon Brook, 0.6 mi upstream from mouth, and $0.8 \mathrm{mi}$ northeast of Frost Valley.

DRAINAGE AREA. $3.72 \mathrm{mi}^{2}$.

\section{WATER-DISCHARGE RECORDS}

PERIOD OF RECORD. June 1983 to September 2006. February to May 1983 (occasional discharge measurements).

GAGE. Water-stage recorder and crest-stage gage. Elevation of gage is 2,060 ft above sea level, from topographic map. Prior to September 11, 1987, at datum $1.00 \mathrm{ft}$ higher.

\section{WATER-QUALITY RECORDS}

PERIOD OF RECORD. May 1991 to September 2006. Phosphorus concentrations began being analyzed in February 1998.

REMARKS. There were 77 samples collected during the 2006 water year. Sixteen storms were sampled with 1-8 samples collected per storm. Total dissolved phosphorus and SRP reached period of record high concentrations during a January 2006 thaw at a discharge of $10.1 \mathrm{ft}^{3} / \mathrm{s}$. Total dissolved aluminum and Almono reached period of record high concentrations at a discharge of $177 \mathrm{ft}^{3} / \mathrm{s}$ during a storm in late June 2006.

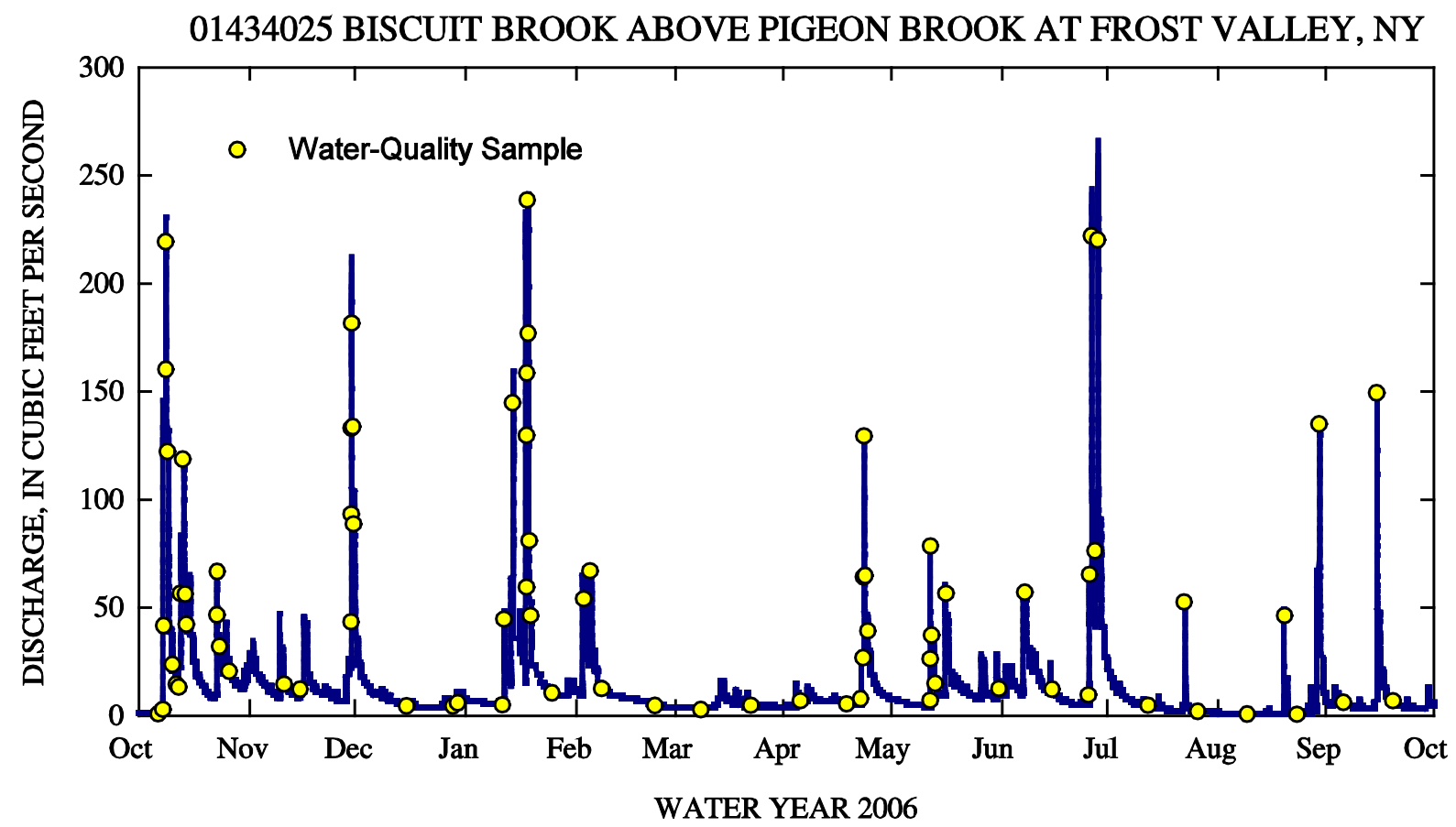




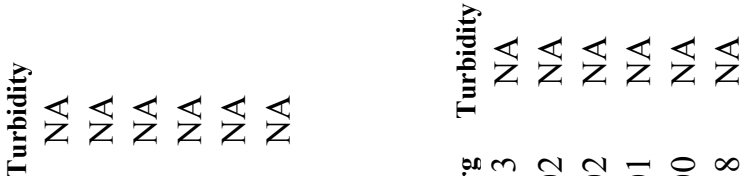

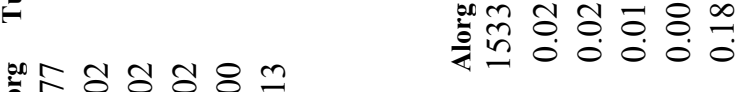

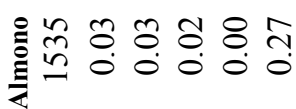

乙

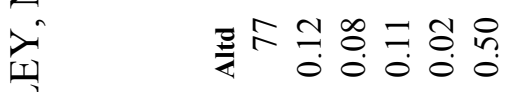

ָิ

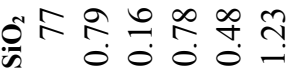

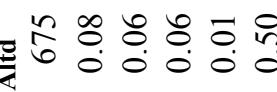

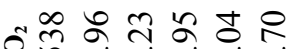

की 00000

范

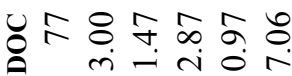

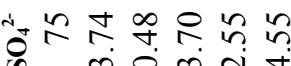

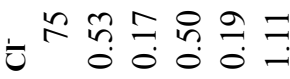

行全

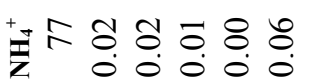

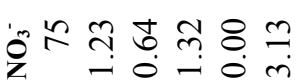

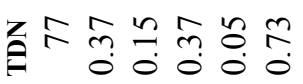

+

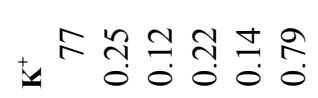

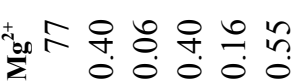

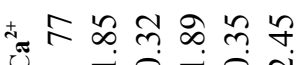

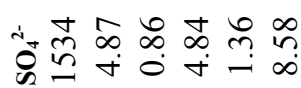

ธ

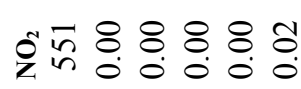

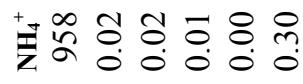

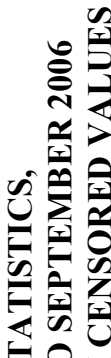

舟은

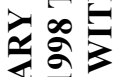

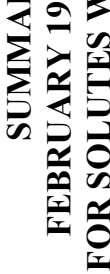

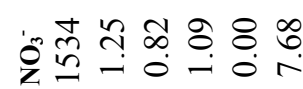

ไñ

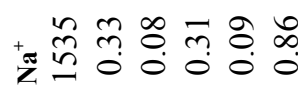

춘

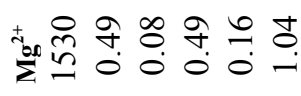

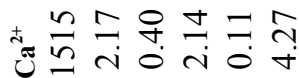

츄

द

출

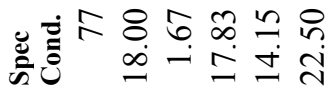

言

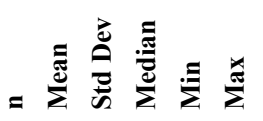

춘유

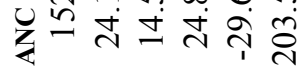

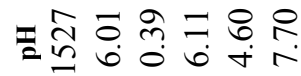

递芒芯

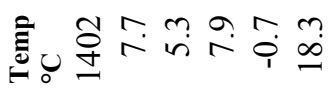

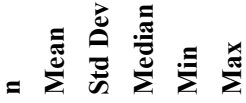

粗艺苂艺苂艺苂苂

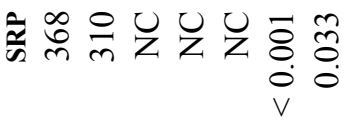

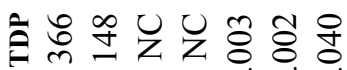
0 i 0

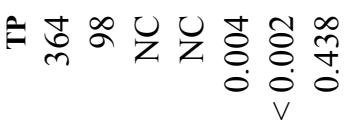

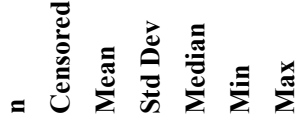

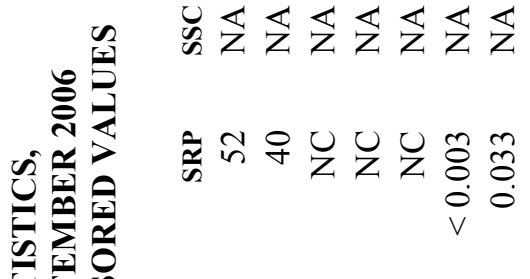

近最

战牙

은

耀

$\sum \widetilde{N}$

舟

0
0
0

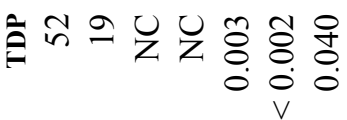

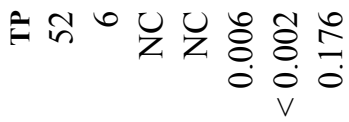

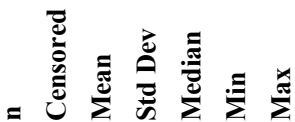




\section{DELAWARE RIVER BASIN}

\section{EAST BRANCH NEVERSINK RIVER NORTHEAST OF DENNING, NY}

LOCATION. lat. $41^{\circ} 58^{\prime} 01^{\prime \prime}$, long. 74 26'54", Ulster County, Hydrologic Unit 02040104, on right bank 0.3 mi upstream from Tray Mill Brook, and 2.3 mi northeast of Denning.

DRAINAGE AREA. $8.93 \mathrm{mi}^{2}$.

\section{WATER-DISCHARGE RECORDS}

PERIOD OF RECORD. October 1990 to September 2006. Occasional discharge measurements, water years 1988-90.

GAGE. Water-stage recorder and crest-stage gage. Elevation of gage is 2,140 ft above sea level, from topographic map.

\section{WATER-QUALITY RECORDS}

PERIOD OF RECORD. May 1991 to September 2006. Phosphorus concentrations began being analyzed in February 1999.

REMARKS. There were 62 samples collected during the 2006 water year. Ten storms were sampled with 1-6 samples collected per storm. All sample concentrations were within the range of concentrations measured previously.

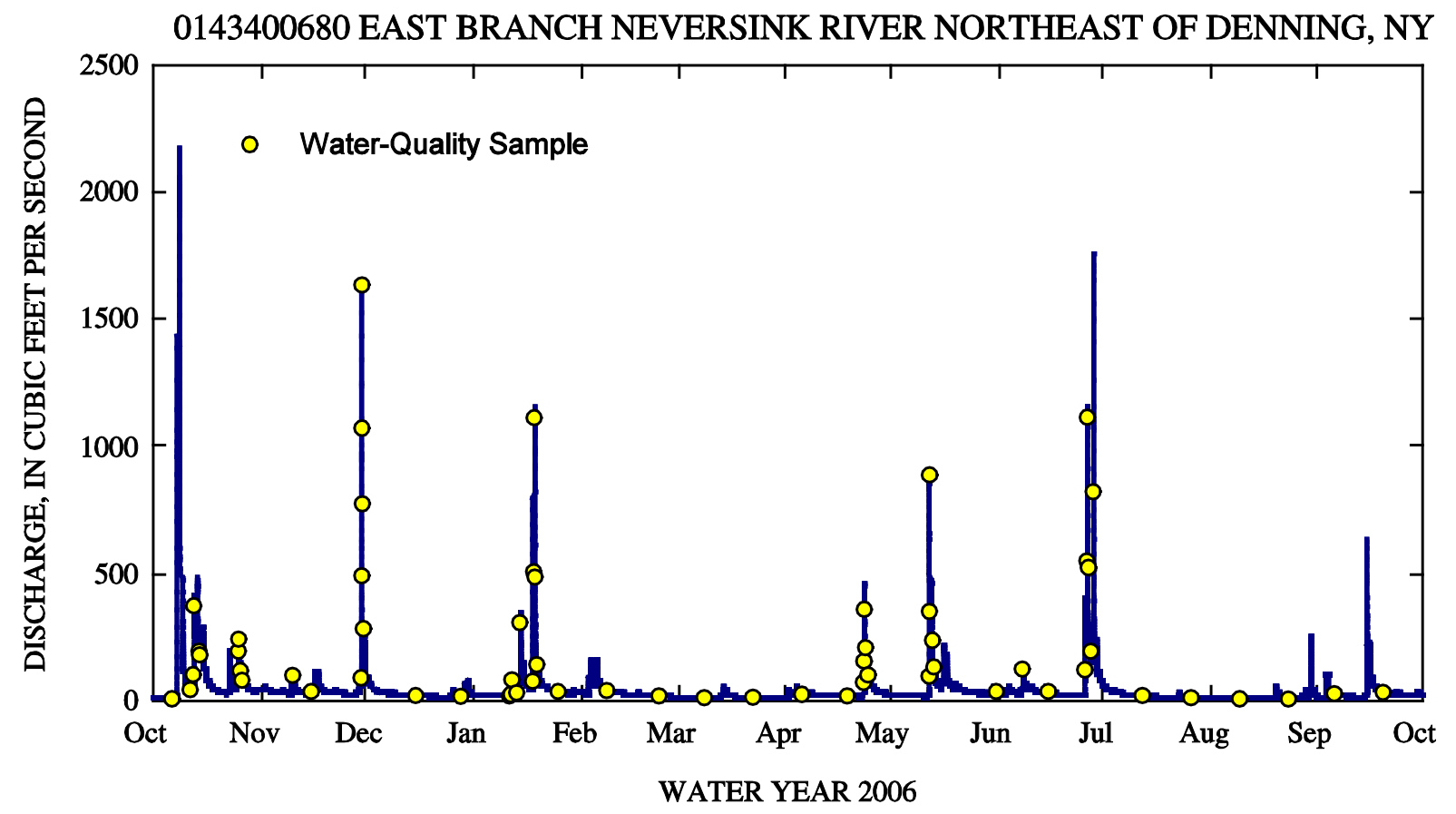




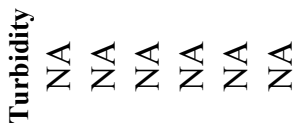

荘

产

픈 군

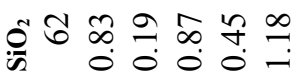

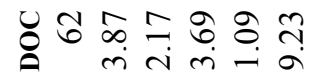

i.

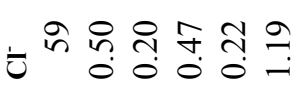

$\overbrace{}^{2}$

苛

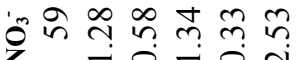

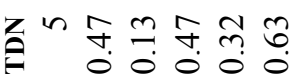

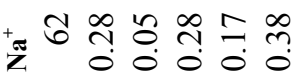

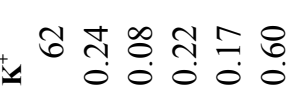

垪

ก

चَ สู

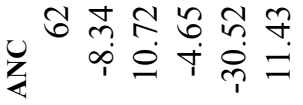

ฐ

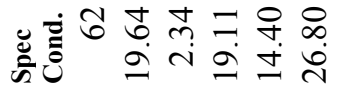

言

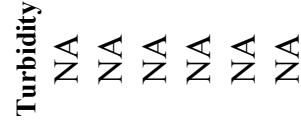

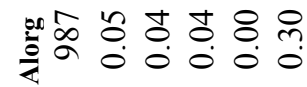

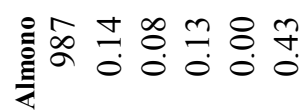

폰

䑻命

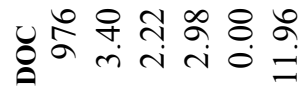

ن்

ธ

彳

स

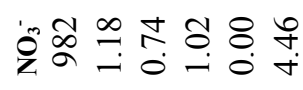

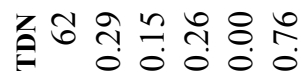

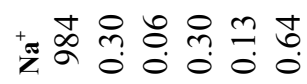

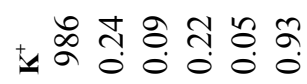

墭䒘

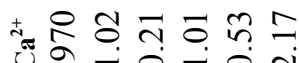

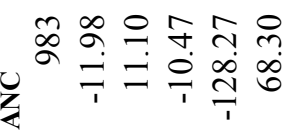

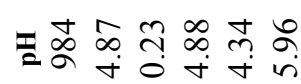

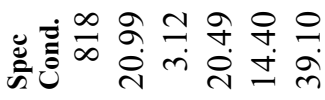

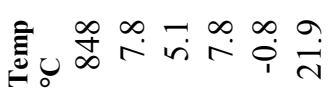

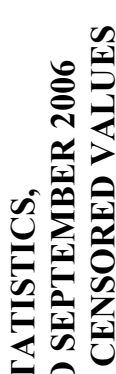

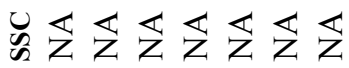

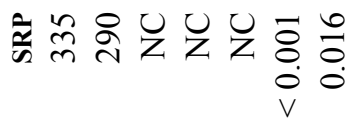

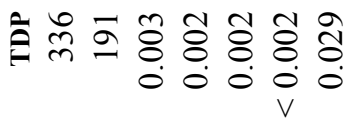

ลे

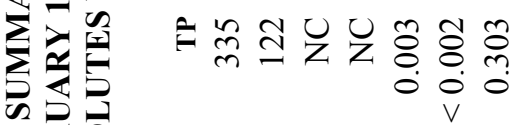

舀㶽

돈 응

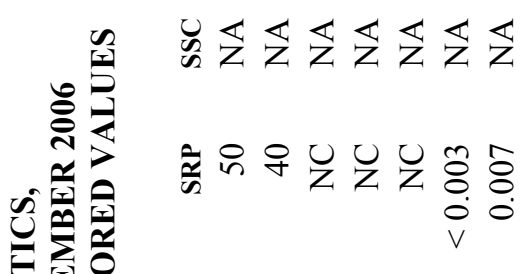

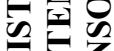

近牙

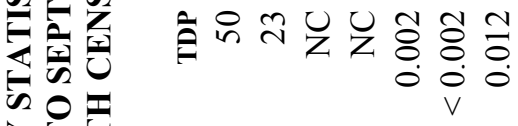

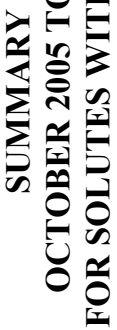

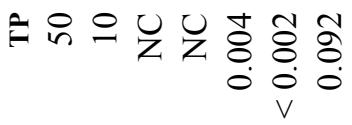

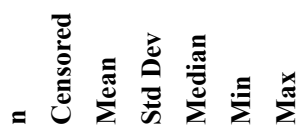




\section{DELAWARE RIVER BASIN}

\section{WEST BRANCH NEVERSINK RIVER AT WINNISOOK LAKE NEAR FROST VALLEY, NY}

LOCATION. lat. $42^{\circ} 00^{\prime} 40^{\prime \prime}$, long. 74 24'53", Ulster County, Hydrologic Unit 02040104, on right bank $0.1 \mathrm{mi}$ southwest of Winnisook Lake, and $4.5 \mathrm{mi}$ northeast of Frost Valley.

DRAINAGE AREA. $0.77 \mathrm{mi}^{2}$.

\section{WATER-DISCHARGE RECORDS}

PERIOD OF RECORD. January 1991 to September 2006.

GAGE. Water-stage recorder and crest-stage gage. Elevation of gage is 2,680 ft above sea level, from topographic map.

\section{WATER-QUALITY RECORDS}

PERIOD OF RECORD. May 1991 to September 2006. Phosphorus concentrations began being analyzed in January 1999.

REMARKS. There were 60 samples collected during the 2006 water year. Nine storms were sampled with 1-7 samples collected per storm. All sample concentrations were within the range of concentrations measured previously.

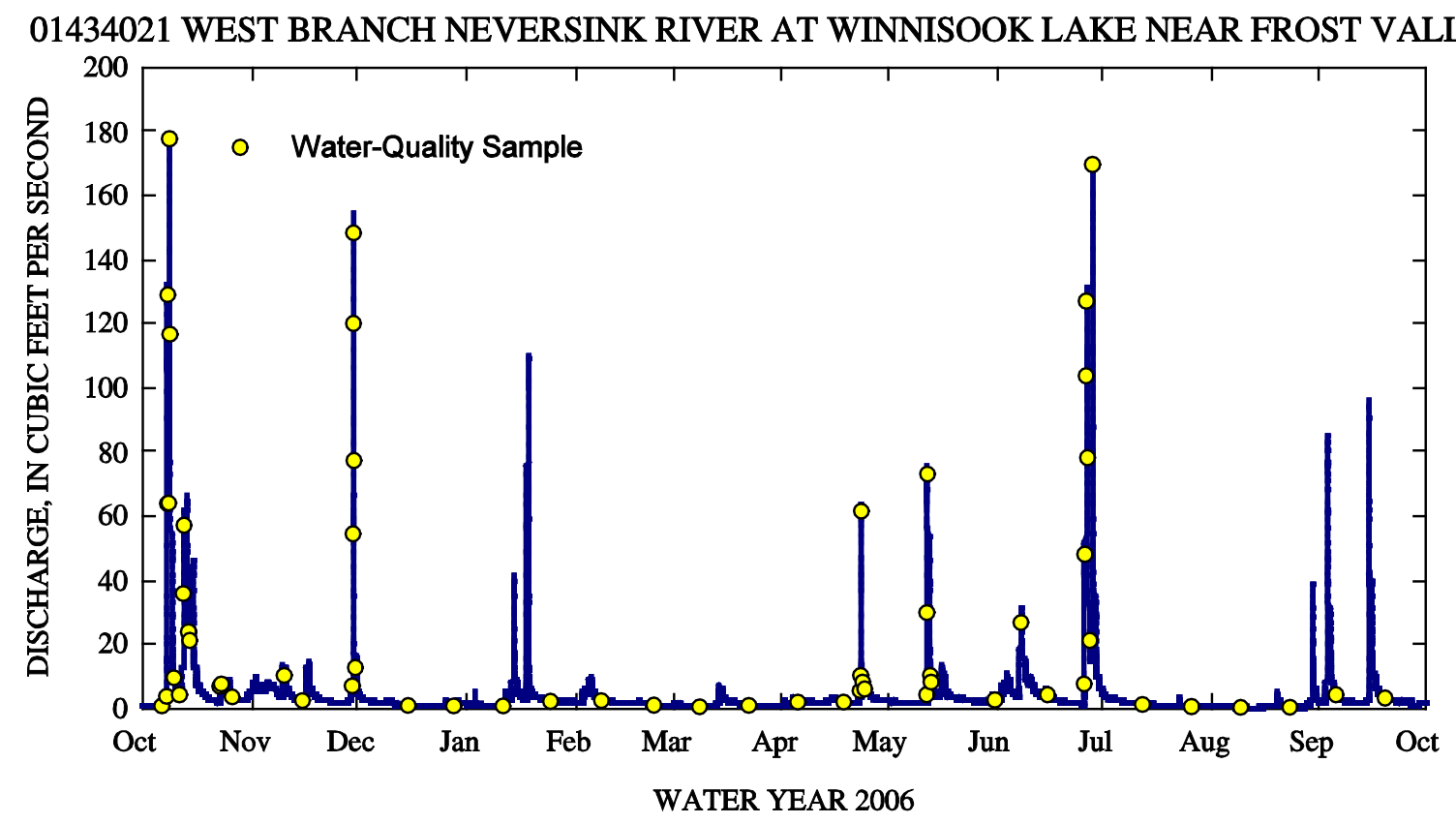


高音艺艺艺艺艺艺

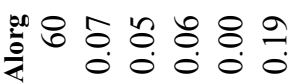

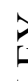

I

选

Z

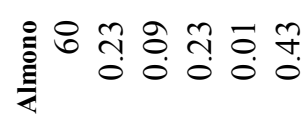

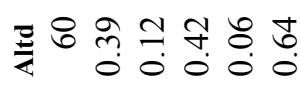

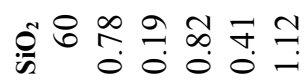

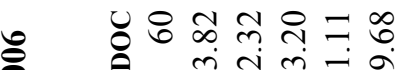

- norant क्षे कि ธ

ঠे

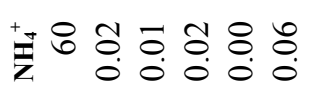

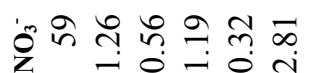

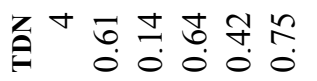

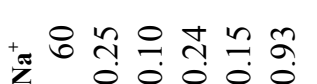

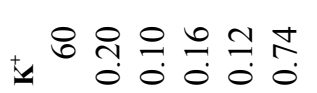

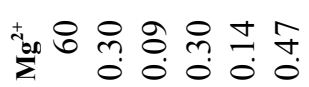

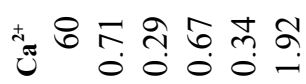

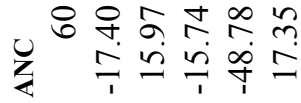

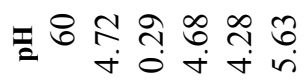

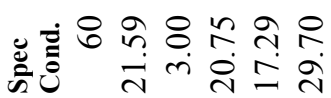
焉

$=$ =

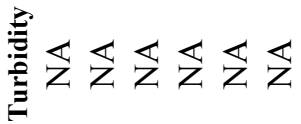

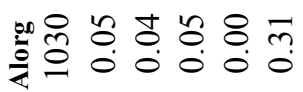

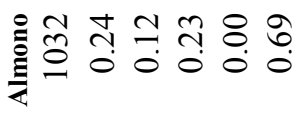

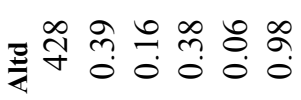

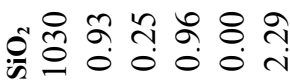

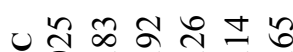

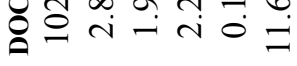

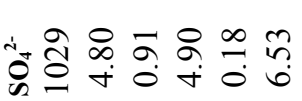

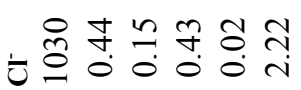

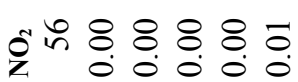

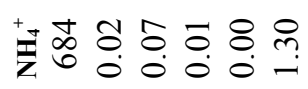

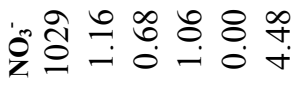

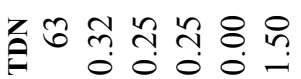

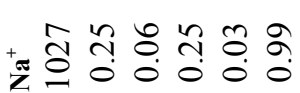
廿

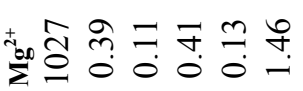

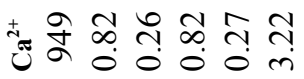

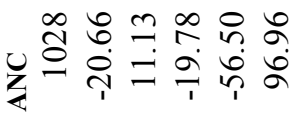

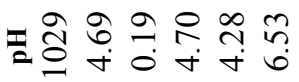

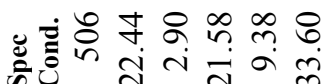
言

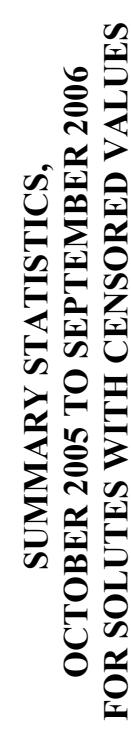

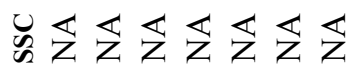

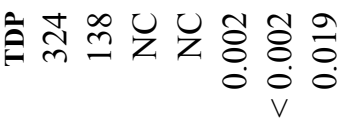

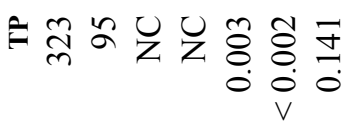

=
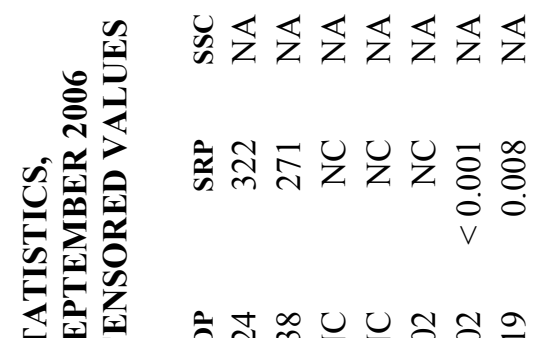

in

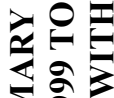

क

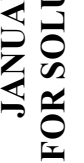

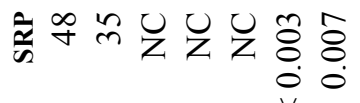

高年는

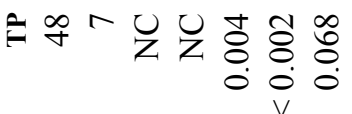

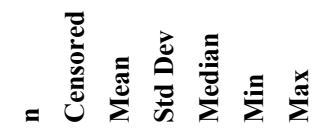




\section{DELAWARE RIVER BASIN}

\section{NEVERSINK RIVER NEAR CLARYVILLE, NY}

LOCATION. lat. 41 53'24", long. 74 35'25", Sullivan County, Hydrologic Unit 02040104, on left bank $50 \mathrm{ft}$ downstream from covered bridge, $300 \mathrm{ft}$ upstream from small tributary, $2.2 \mathrm{mi}$ downstream from confluence of East and West Branches, and $2.2 \mathrm{mi}$ southwest of Claryville. DRAINAGE AREA. $66.6 \mathrm{mi}^{2}$.

\section{WATER-DISCHARGE RECORDS}

PERIOD OF RECORD (Revised). November 1937 to May 1949, July 1951 to September 2006. Prior to July 1951, published as "at Halls Mills near Curry" (01435500).

REVISED RECORDS (Revised). WDR NY-75-1: Gage datum. WDR NY-82-1: Drainage area. GAGE. Water-stage recorder. Elevation of gage is $1,522.37 \mathrm{ft}$ above sea level from topographic map. Prior to October 1, 1974, at datum $6.00 \mathrm{ft}$ higher. October 1, 1974 to September 30, 1979, at datum $5.00 \mathrm{ft}$ higher. November 1937 to May 1949, at site $1.3 \mathrm{mi}$ downstream at elevation $1,470 \mathrm{ft}$, from topographic map.

\section{WATER-QUALITY RECORDS}

PERIOD OF RECORD. July 1991 to September 2006. Phosphorus concentrations began being analyzed in June 1998.

REMARKS. There were 70 samples collected during the 2006 water year. Nine storms were sampled with 2-7 samples collected per storm. Total dissolved aluminum reached a period of record high concentration at a discharge of $536 \mathrm{ft}^{3} / \mathrm{s}$ during a small storm in mid-November 2005.

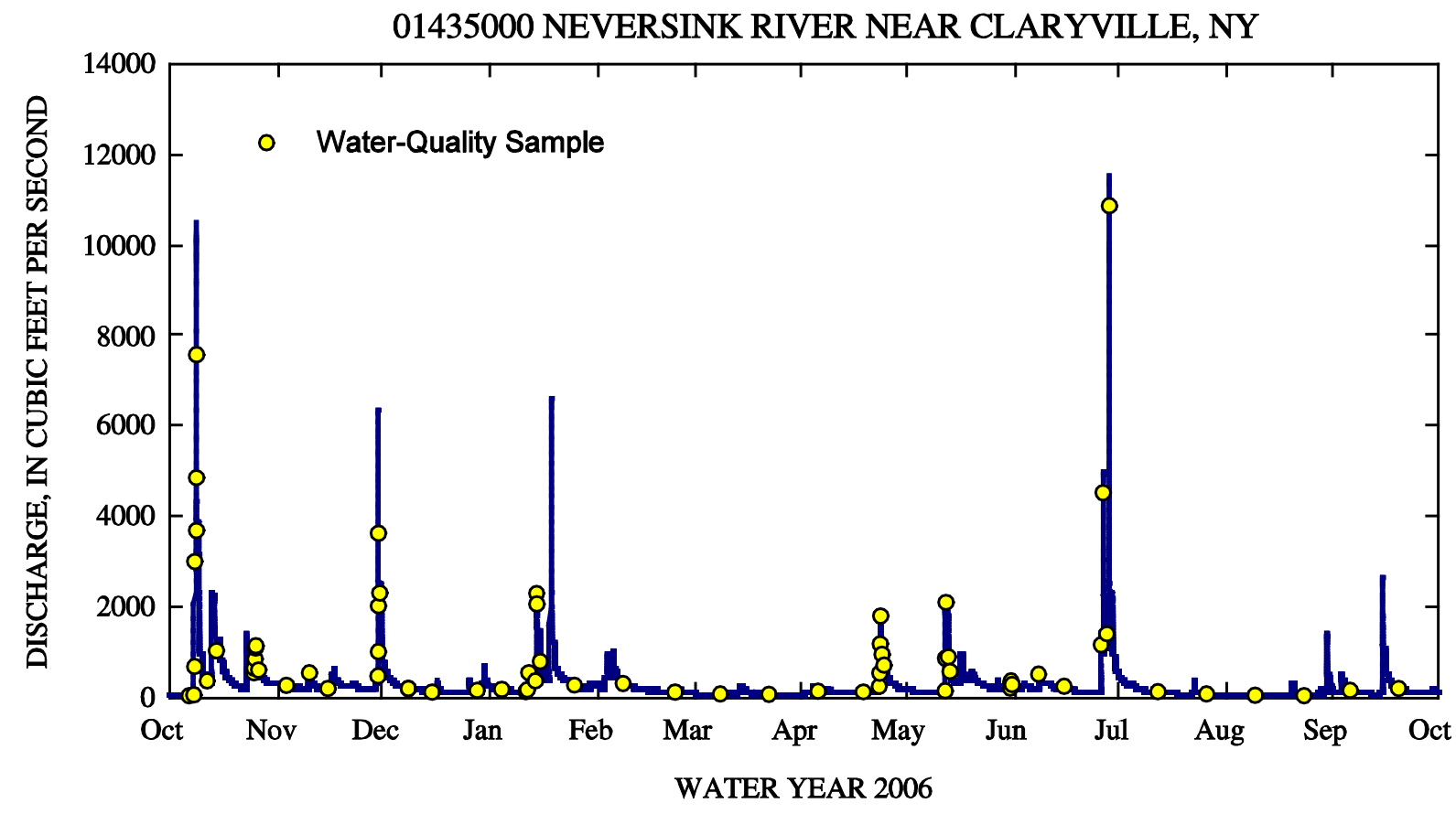




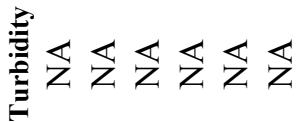

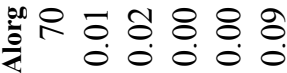

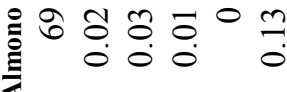

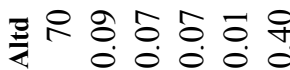

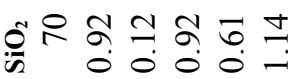

章

\pm तु०

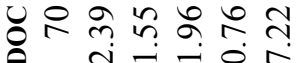

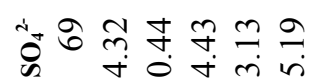

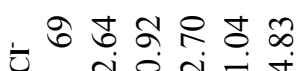

彳

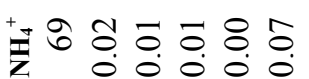

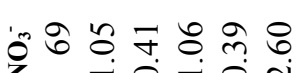

$-0-0 \mathrm{i}$

दूล

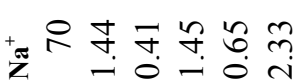

유유을 줌

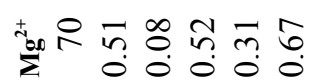

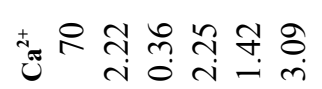

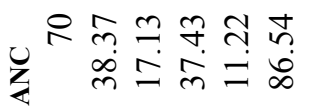

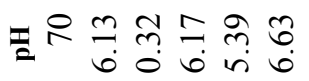

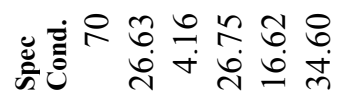

言割

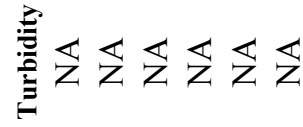

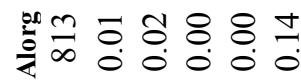

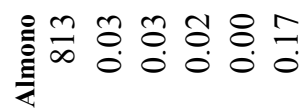

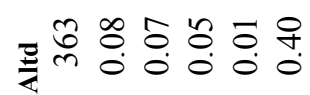

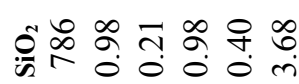

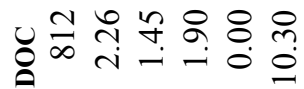

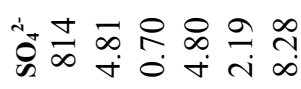

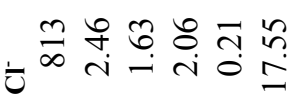

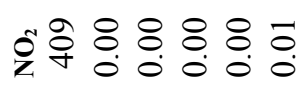

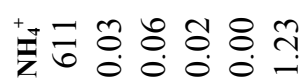

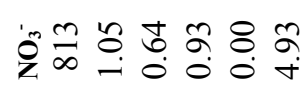

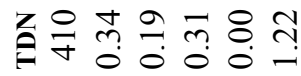

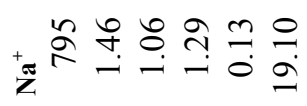

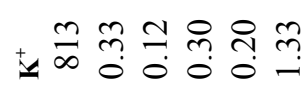

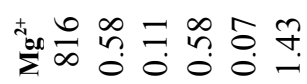

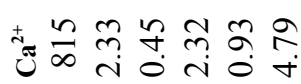

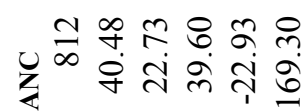

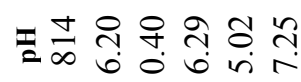

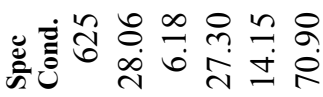

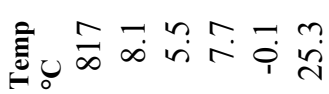

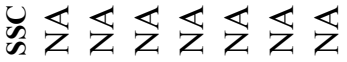

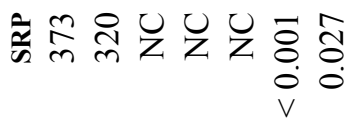

ขึํํㅇำ

我识

运空

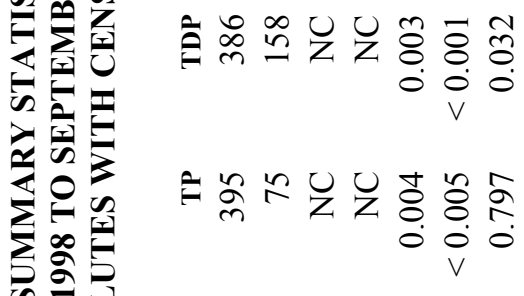

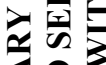

$\sum_{\infty}^{\infty} \delta$

잠

은

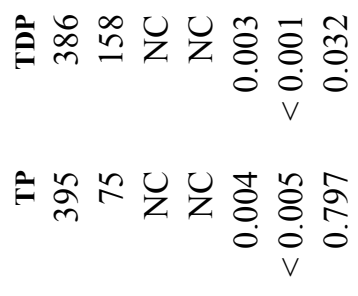

=

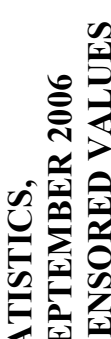

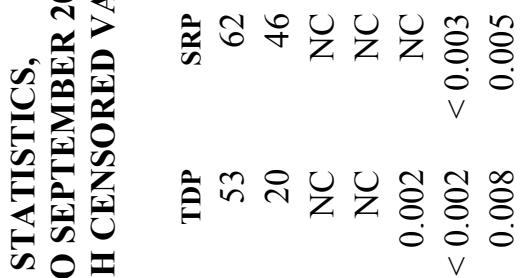

is 0

का

的象

㱐

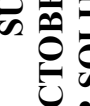

包

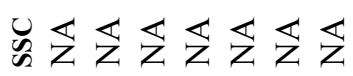

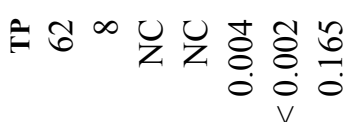

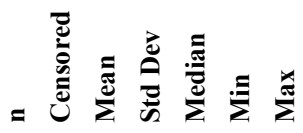

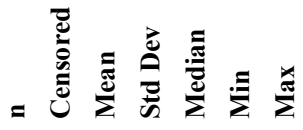




\section{HUDSON RIVER BASIN}

\section{BEAVER KILL TRIBUTARY ABOVE LAKE HILL, NY}

LOCATION. lat. $42^{\circ} 04^{\prime} 59^{\prime \prime}$, long. $74^{\circ} 10^{\prime} 59^{\prime \prime}$, Ulster County, Hydrologic Unit 02020006 , on left bank about $500 \mathrm{ft}$ upstream from confluence with Beaver Kill, and $1.2 \mathrm{mi}$ north of Lake Hill. DRAINAGE AREA. $0.98 \mathrm{mi}^{2}$.

\section{WATER-DISCHARGE RECORDS}

PERIOD OF RECORD. July 2000 to September 2006

GAGE. Water-stage recorder and crest-stage gage. Elevation of gage is 1,300 ft above NGVD of 1929, from topographic map.

\section{WATER-QUALITY RECORDS}

PERIOD OF RECORD. October 1997 to September 2006.

REMARKS. There were 58 samples collected during the 2006 water year. Nine storms were sampled with 1-6 samples collected per storm. Chloride reached a period of record high concentration at a discharge of $16.7 \mathrm{ft}^{3} / \mathrm{s}$ during a storm in late November. Nitrate reached a period of record high concentration at a discharge of $24.9 \mathrm{ft}^{3} / \mathrm{s}$ during a large storm in late June 2006. Sample water temperature reached a period of record high at a discharge of $0.06 \mathrm{ft}^{3} / \mathrm{s}$ in early August 2006.

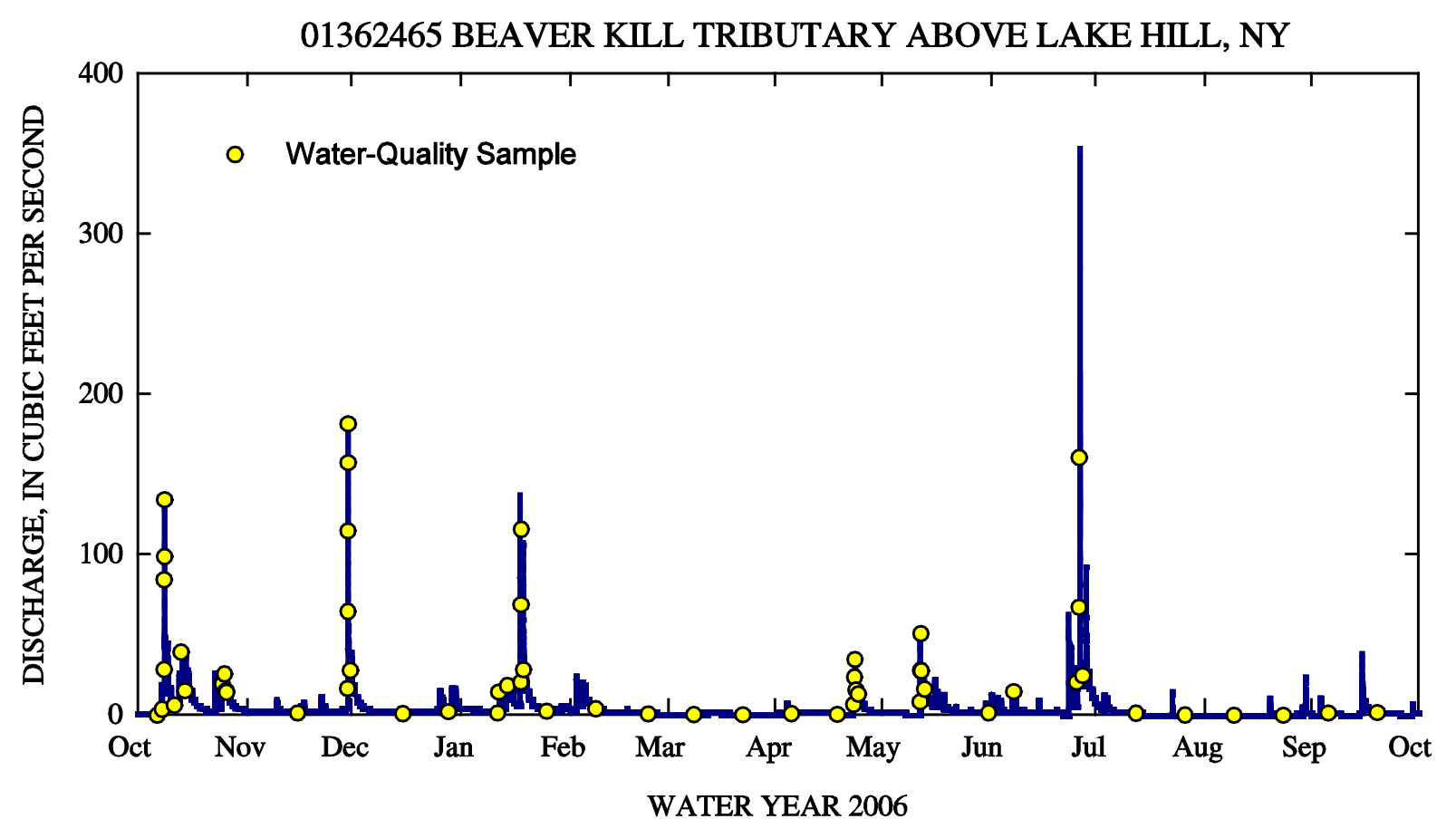


눌

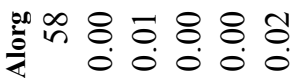

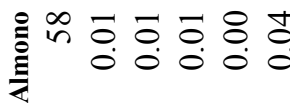

픈

응

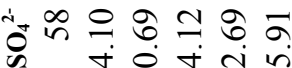

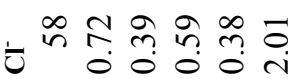

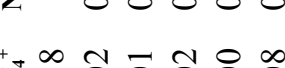

z

in in

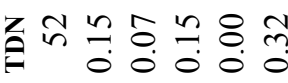

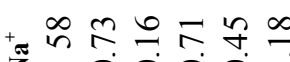

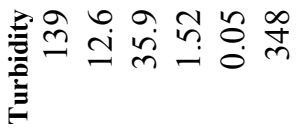

㐫充

ำ

$\infty-a n m+$

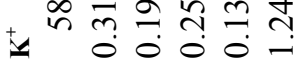

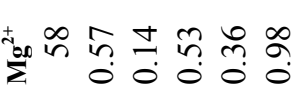

+

in

女 iिं

픈 웡 đ?

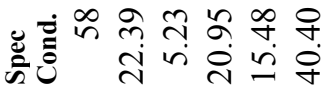

产

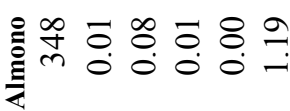

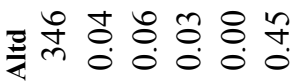

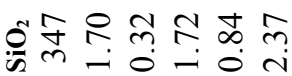

ㅇํㅇ 웅

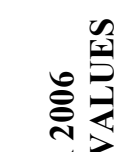

की 논

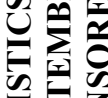

田

这究

की 0

든

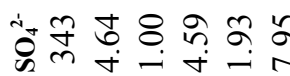

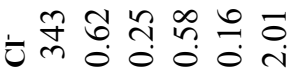

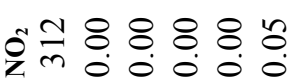

沶尔

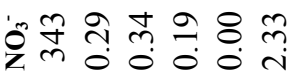

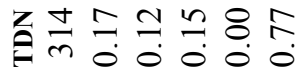

+

零

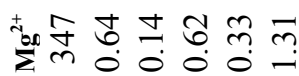

むٓ

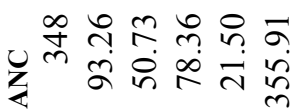

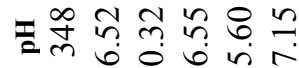

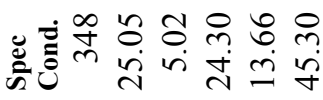

言
产拣

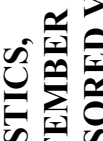

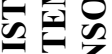

透

is 0

$\lambda$

的政

路

हैำ

ข้
产

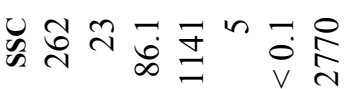

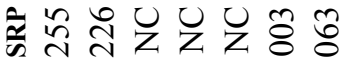
$\circ 0$

茵

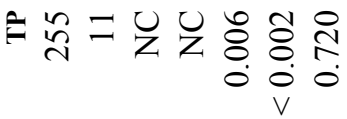

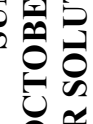

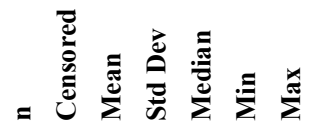

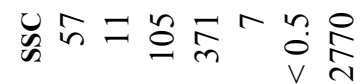

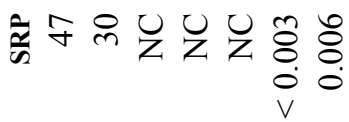

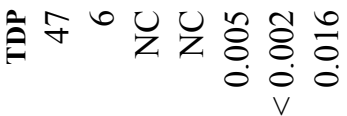

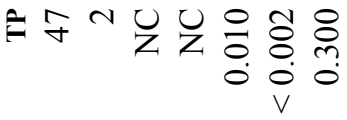

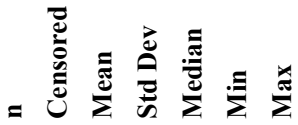




\section{HUDSON RIVER BASIN}

\section{RONDOUT CREEK ABOVE RED BROOK AT PEEKAMOOSE, NY}

LOCATION. lat. $41^{\circ} 56^{\prime} 13^{\prime \prime}$, long. 74 22'30", Ulster County, Hydrologic Unit 02020007, $500 \mathrm{ft}$ upstream from mouth of Red Brook, 0.8 mi upstream from outlet of Peekamoose Lake, and 0.8 mi north of Peekamoose.

DRAINAGE AREA. $5.36 \mathrm{mi}^{2}$.

\section{WATER-DISCHARGE RECORDS}

PERIOD OF RECORD. May 1996 to September 2006. Occasional discharge measurements, water years 1984-86, 1988-94.

GAGE. Water-stage recorder and crest-stage gage. Elevation of gage is 1,740 ft above sea level, from topographic map.

\section{WATER-QUALITY RECORDS}

PERIOD OF RECORD. May 1991 to September 2006.

REMARKS. There were 65 samples collected during the 2006 water year. Nine storms were sampled with a range of 1-13 samples collected per storm. Chloride reached a period of record high concentration in late June 2006 at a discharge of $11.6 \mathrm{ft}^{3} / \mathrm{s}$. Sample water temperature reached a period of record high of $18.8^{\circ} \mathrm{C}$ at a discharge of $4.0 \mathrm{ft}^{3} / \mathrm{s}$ in early August 2006 .

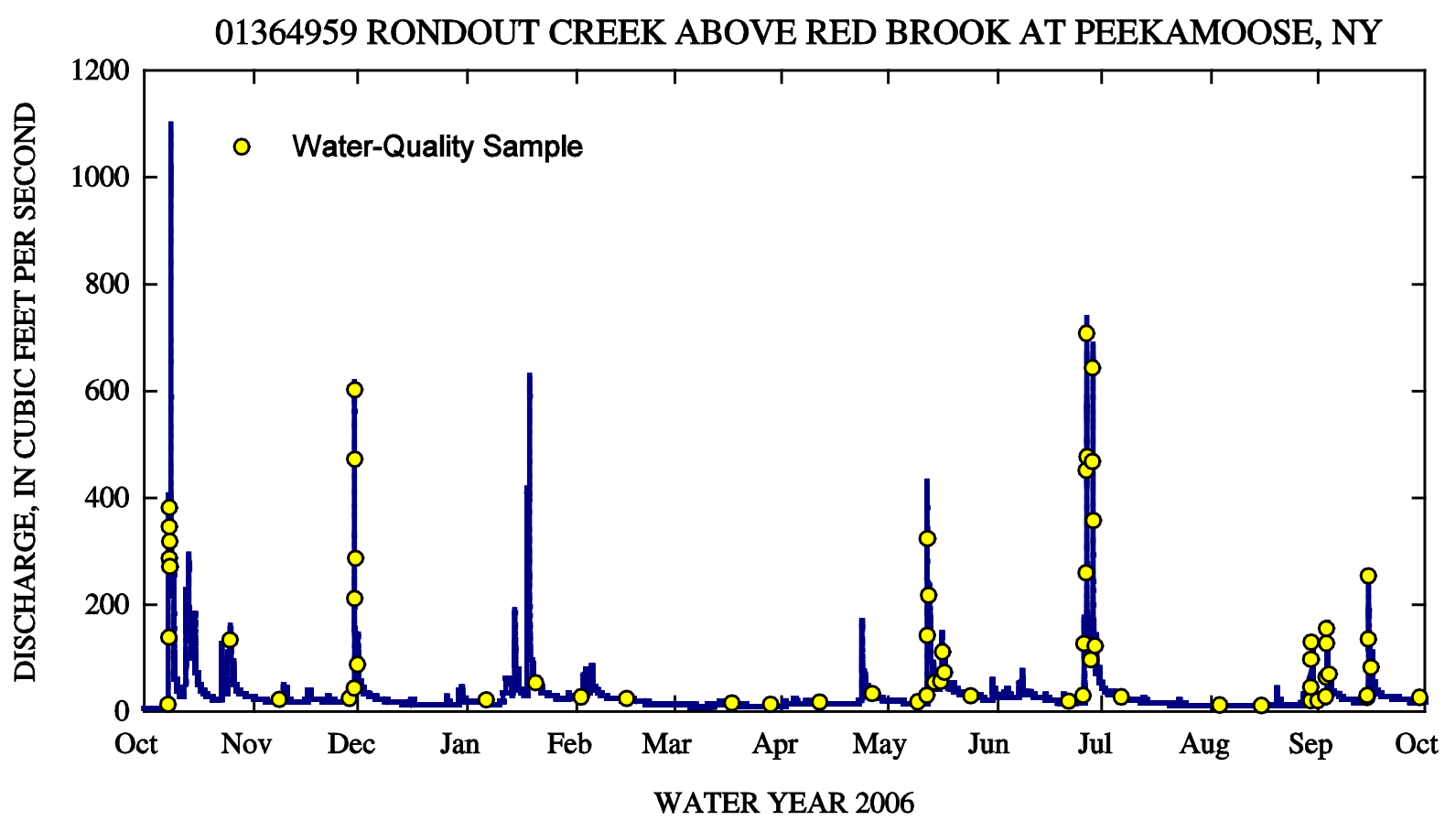




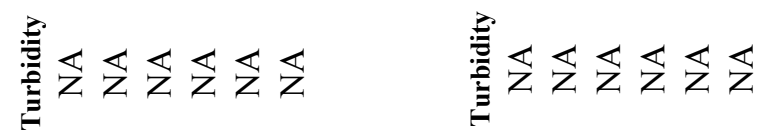

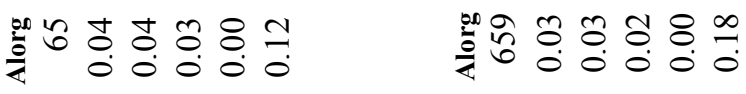

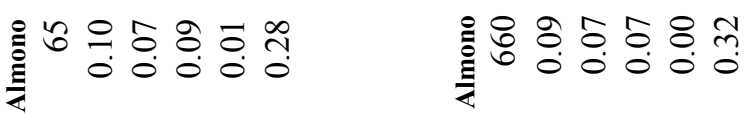

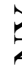

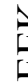

$\frac{1}{2}$

穵

$\checkmark$

党

西

됟

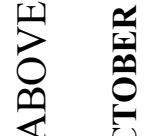

政

떼

\begin{tabular}{l}
0 \\
5 \\
0 \\
0 \\
0 \\
\hdashline
\end{tabular}

â

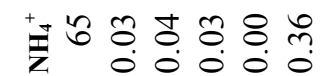

छ

ஸี่

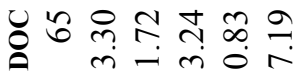

宗艺艺艺艺

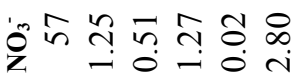

Zิ

+

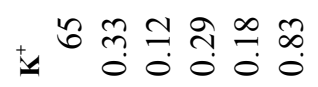

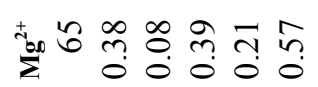

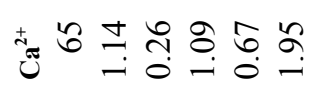

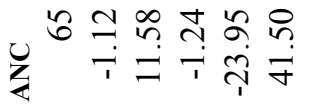

=

苛

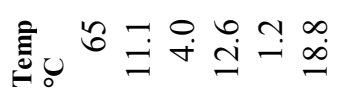

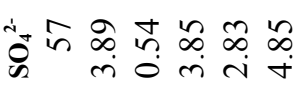

ธ
छ

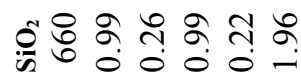

윰 宅昌

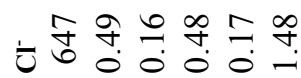
గ゙

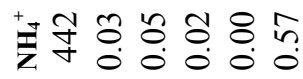

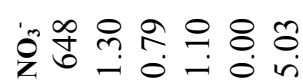

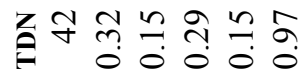

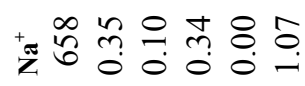

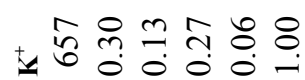

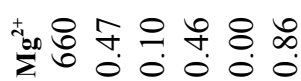

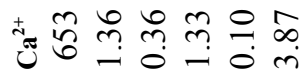

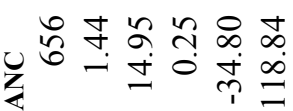

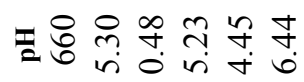

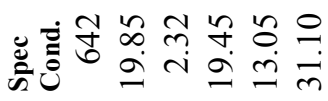

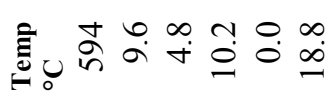

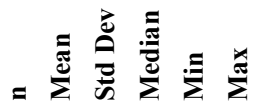

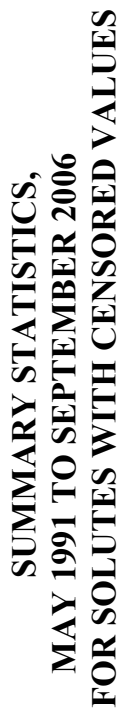

语艺危死艺艺

产艺不艺艺危

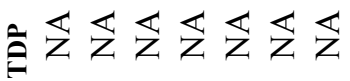

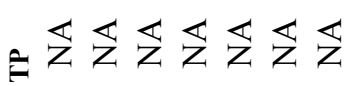

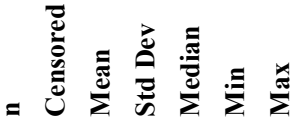

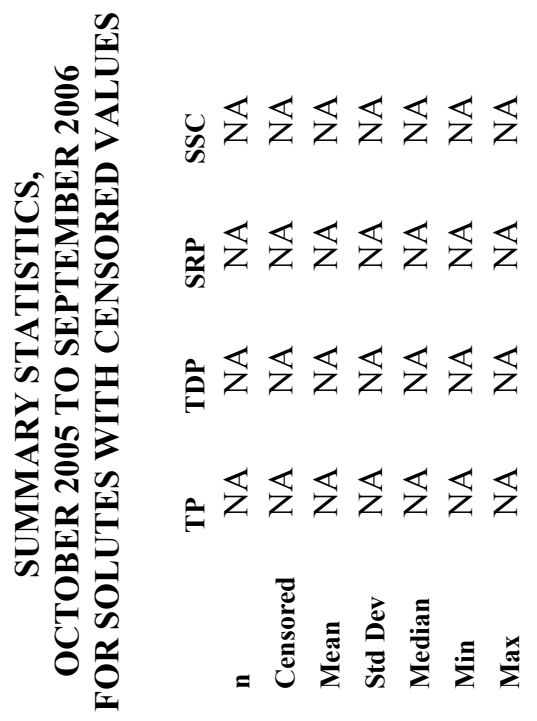

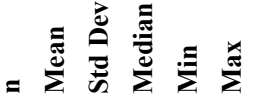




\section{References Cited}

Fishman, M.J., 1993, Methods of analysis by the U.S.

Geological Survey National Water Quality Laboratory determination of inorganic and organic constituents in water and fluvial sediments: U.S. Geological Survey Open-File Report 93-125, 217 p.

Helsel, D.R., 2005, Nondetects and data analysis: Statistics for censored environmental data: Hoboken, N.J., John Wiley \& Sons, 268 p.

Henshaw, J.M., Lewis, T.E., and Heithmar, E.M., 1988, A semi-automated colorimetric method for the determination of monomeric aluminum species in natural waters by flow injection analysis: International Journal of Environmental Analytical Chemistry, v. 34, p. 119-135.

Lawrence, G.B., Lincoln, T.A., Horan-Ross, D.A., Olson, M.L., and Waldron, L.A., 1995, Analytical methods of the U.S. Geological Survey's New York District water-analysis laboratory: U.S. Geological Survey Open-File Report 95-416, $78 \mathrm{p}$.

Lincoln, T.A., Horan-Ross, D.A., McHale, M.R., and Lawrence, G.B., 2006a, Quality-assurance data for routine water analyses by the U.S. Geological Survey Laboratory in Troy, New York—July 1999 through June 2001: U.S. Geological Survey Open-File Report 2006-1246, 27 p.

Lincoln, T.A., Horan-Ross, D.A., McHale, M.R., and Lawrence, G.B., 2006b, Quality-assurance data for routine water analyses by the U.S. Geological Survey Laboratory in Troy, New York—July 1997 through June 1999: U.S. Geological Survey Open-File Report 2006-1245, 25 p.

National Climatic Data Center, 2007, Climate of 2006in historical perspective: National Climatic Data Center, accessed May 2008, at http://www.ncdc.noaa.gov/oa/ climate/research/2006/ann/ann06.html.

United States Geological Survey, variously dated, National field manual for the collection of water-quality data: U.S. Geological Survey Techniques of Water-Resources Investigations, book 9, chaps. A1-A9, available at http://pubs.water.usgs.gov/twri9A. 
Prepared by the Pembroke Publishing Service Center.

For additional information write to:

New York Water Science Center

U.S. Geological Survey

425 Jordan Road

Troy, NY 12180

Information requests:

(518) 285-5602

or visit our Web site at: http://ny.water.usgs.gov 

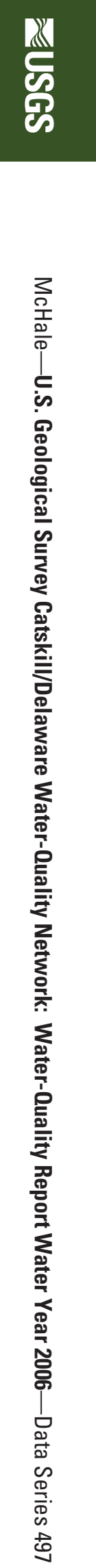